\title{
Analysis of the geochemical variability in lepisosteid scales from the Fontllonga-3 site (early Danian, Tremp Formation, South Central Pyrenees, Spain): Implications for palaeoenvironmental studies
}

\author{
Laura Domingo ${ }^{\text {a,*, }}$, Stephen T. Grimes ${ }^{b}$, Rodrigo Soler-Gijón ${ }^{\text {a,c }}$, Nieves López-Martínez ${ }^{\text {a }}$ \\ a Dept. Paleontologí, Facuitad CC. Geológicas, Universidad Complutense de Madrid, 28040 Madrid, Spain \\ b School of Earth, Ocean and Environmental Sciences, University of Plymouth, Drake Circus, PLA 8AA Plymouth, Devon, United Kingdom \\ ${ }^{c}$ Iustitut für Paläontologie, Museum für Naturkunde Hurnboldt Universität, D-10115 Berlin, Germany
}

Keywords:

Lepisosteid scales

Ganoine

Isopedine

$\mathrm{Ba} / \mathrm{Ca}$ palaeothermometer

${ }_{0}^{18} \mathrm{O}_{\mathrm{PO}}$ palaeothermometer

Fontllonga-3

\begin{abstract}
A B S T R A C T
Rare Earth Element (REE), $\mathrm{Ba} / \mathrm{Ca}, \mathrm{Sr} / \mathrm{Ca}$ and $\delta^{18} \mathrm{O}_{\mathrm{p} O 4}$ analyses have been performed on the ganoine and isopedine of different types of isolated scales (anterior, middle, posterior flank scales and dorsal body margin scales) from juvenile lepisosteids from the Font tlonga-3 site (early Danian, Tremp Formation, South-Central Pyrenees, Spain) with the aim of detecting the most suitable kind of scale to be used in palaeoclimate studies. The REE flat-shape patterns obtained in lepisosteid scales from Fontllonga-3 are indicative of the absence of late stage diagenesis and recrystallization and have confirmed the identification of the palaeoenvironment where the Fontllonga- 3 lepisosteids inhabited to be that of an estuary. The $\mathrm{Ba} / \mathrm{Ca}$ palaeothermometer shows that posterior flank scales record on average $4.52^{\circ} \mathrm{C}$ (ganoine) and $3.49^{\circ} \mathrm{C}$ (isopedine) higher temperatures when compared to middle flank scales, which may be related to the fact that posterior flank scales grow preferentially during the warm season, whilst middle flank scales, which have the greatest number of layers of ganoine per unit of time and grow all year round, record a greater amplitude with respect to palaeoenvironmental and palaeoclimatic variations. Temperature values obtained from anterior flank scales follow a pattern similar to that showed by middle flank scales, whilst temperature values provided by dorsal scales resemble the pattern furnished by posterior flank scales. The same relationship between scale position and temperature but to a lesser degree $\left(1.48{ }^{\circ} \mathrm{C}\right)$ is also evident in the calculated $\delta^{18} \mathrm{O}_{\mathrm{PO}}$ temperatures. The $\mathrm{Ba} / \mathrm{Ca}$ palaeothermometer was applied by considering $\mathrm{Ba} / \mathrm{Ca}$ ratios of the water for different types of environments and it has been found out that a ratio similar to that of marine waters yielded the best approximation to $\delta^{18} \mathrm{O}_{\mathrm{PO} 4}$ temperatures $\left(29.82 \pm 3.76^{\circ} \mathrm{C}\right)$. The mean $\mathrm{Ba} / \mathrm{Ca}$ temperature value obtained from the analysis of all the ganoine samples $\left(26.96 \pm 5.72{ }^{\circ} \mathrm{C}\right)$ is also consistent with the temperature of the water in which extant relatives of osteoglossiform fish, whose remains have been found in Fontllonga- 3 along with lepisosteid remains, inhabit nowadays $\left(24-40{ }^{\circ} \mathrm{C}\right.$, with mean values of 27 to $32{ }^{\circ} \mathrm{C}$ ). The mean $\mathrm{Ba} / \mathrm{Ca}$ temperature values furnished by the isopedine are lower than that obtained on the ganoine which may be due to minor diagenetic alteration. On account of these results, it is recommended that a distinction should be made between different types of scales as this could provide information concerning the summer growth temperature (posterior flank scales) as well as the annual temperature range (middle flank scales). Furthermore, it is recommended that ganoine be used in all studies as it appears to be the most resistant tissue in lepisosteid scales to diagenetic alteration.
\end{abstract}

\section{Introduction}

The use of the oxygen isotope composition of phosphate is a valuable analytical tool with which to investigate past climatic conditions and palaeoecological patterns as recorded in fossil vertebrates (Bryant et al., 1994; Grimes et al., 2003; Lécuyer et al., 2003a; Pucéat et al., 2003; Amiot et al., 2004; Tütken et al., 2004;
Grimes et al, 2005; Billon-Bruyat et al., 2005; Tütken et al., 2006). In particular, lepisosteid scales have been widely used in the study of past climate change (Fricke et al., 1998; Barrick et al., 1999; Grimes et al., 2003; Amiot et al., 2004; Fricke and Wing, 2004; Grimes et al., 2005; Fricke and Pearson, 2008; Fricke et al., 2008; Matson and Fox, 2008). However, none of these previous lepisosteid studies has taken into account the type of scale that was analysed. When dealing with mammal teeth, it is a well known fact that depending on the type of tooth analysed, the isotopic values which are obtained vary slightly as a consequence of the different time of development of each tooth in 
the jaw. Following this premise, it is important to determine which is the most suitable type of tooth to analyse (Bryant et al., 1996; Feranec and MacFadden, 2000; Fox and Fisher, 2004; Feranec, 2004; Sponheimer and Lee-Thorp, 2006). It has also been observed that, in a similar manner to teeth, the formation of the scales on a fish body follows a well established pattern (Sire et al., 1997; Sire and Akimenko, 2004). These authors have shown that middle flank scales, which record a higher number of growth lines, grow all year round. Therefore, these scales should provide an average seasonal signal and thus, a higher variability in the geochemical records. On the other hand, the scales from the posterior part of a fish have been shown to develop more during the warm season and hence, their geochemical signal should provide information about this season as well as supplying a lower geochemical variability (R. Soler-Gijón, pers. obs.).

$\mathrm{The} \mathrm{Ba} / \mathrm{Ca}$ palaeothermometer was recently derived by Balter and Lécuyer (2004) as a new tool enabling temperature values to be calculated from the $\mathrm{Ba} / \mathrm{Ca}$ ratio in fossil bioapatites. The experimental work, which led to the derivation of the palaeothermometry equation, was based upon the inorganic precipitation of apatite between $5{ }^{\circ} \mathrm{C}$ and $60{ }^{\circ} \mathrm{C}$. By applying this inorganic derived palaeothermometer to a fossil site around the Cretaceous-Tertiary boundary (KTb), and as a result of obtaining similar palaeotemperatures to those calculated by another independent method, Balter and Lécuyer (2004) argued that their new $\mathrm{Ba} / \mathrm{Ca}$ palaeothermometer could be applied to fossil bioapatite. However, they did also state that before the $\mathrm{Ba} / \mathrm{Ca}$ palaeothermometer was applied to the fossil record it is important to demonstrate that there had not been any significant diagenetic alteration which could have altered the primary $\mathrm{Ba} / \mathrm{Ca}$ ratio of the fossil material analysed.

The main objective of this study is to test the aforementioned assumptions by providing a thorough characterization of the $\mathrm{Ba} / \mathrm{Ca}$ ratios, $\delta^{18} \mathrm{O}_{\mathrm{PO}}$ values and palaeotemperatures recorded in different types of isolated ganoid scales (anterior, middle and posterior flank and dorsal body margin scales) and tissues (ganoine and isopedine) from a lepisosteid of the Fontllonga-3 site (early Danian, Tremp Formation, South-Central Pyrenees, Spain). Based upon these results this study aims to determine the most suitable type of scale to be used in future palaeoclimatic studies.

\section{Geological setting}

The Fontllonga- 3 site belongs to the Tremp Formation which constitutes the last infilling episode of the Pyrenean basin developed subsequently to the opening of the Bay of Biscay during the Early Cretaceous. The transitional and continental deposits of the Tremp Formation (Late Campanian-Early Eocene) are exposed in the central and western part of the Southern Pyrenees and are underlain and intercalated at their base with the marine Aren Sandstone (Late Campanian-Early Maastrichtian) and overlain by the Ilerdian transgressive Alveolina limestones and marls (Early Eocene) (Mey et al., 1968; Nagtegaal et al., 1983). A palaeolatitude of $35^{\circ} \mathrm{N}$ has been estimated for the South Central Pyrenees during the early Danian (Schmitz and Pujalte, 2003; Fernández-Marrón et al., 2004).

The Montsec thrust separates two large asymmetric synclines oriented W-E, the Tremp syncline in the North from the Ager syncline in the South. The Tremp Formation outcrops in the core of these two major synclines (Fig. 1). In the Fontllonga section (Ager syncline), the Tremp Formation comprises up to $1000 \mathrm{~m}$ of peritidal and lacustrine grey limestones, reddish claystones and estuarine sandstones organized in four units; two carbonate (Units 1 and 3) and two terrigenous units (Units 2 and 4) (Galbrun et al., 1993).

Biostratigraphy (pollen, charophytes, dinosaurs and other vertebrates), palaeomagnetism and stable isotope studies have all been used to date the Tremp Formation (Feist and Colombo, 1983; Galbrun et al., 1993; López-Martínez et al., 1998, 1999; Mayr et al., 1999; Fernández-Marrón et al., 2004). The Fontllonga section is the longest and the most continuous palaeomagnetic succession across the KTb in continental deposits from Europe.

The Fontllonga-3 site has been correlated to the top of chron C29r (lower Danian). It is a lenticular clay bed interpreted as an ox-bow lake fill, intercalated in the uppermost part of a thickening upward sequence of channelled sandstone bodies, up to $15 \mathrm{~m}$ thick, which shows lateral accretion (point bar structure) and sigmoidal stratification, indicating tidal influences. This sandstone unit can be correlated across the $30 \mathrm{~km}$ wide Ager syncline and has been interpreted as an estuary deposit (Âlvarez-Sierra et al., 1994; López-Martínez et al., 1998).

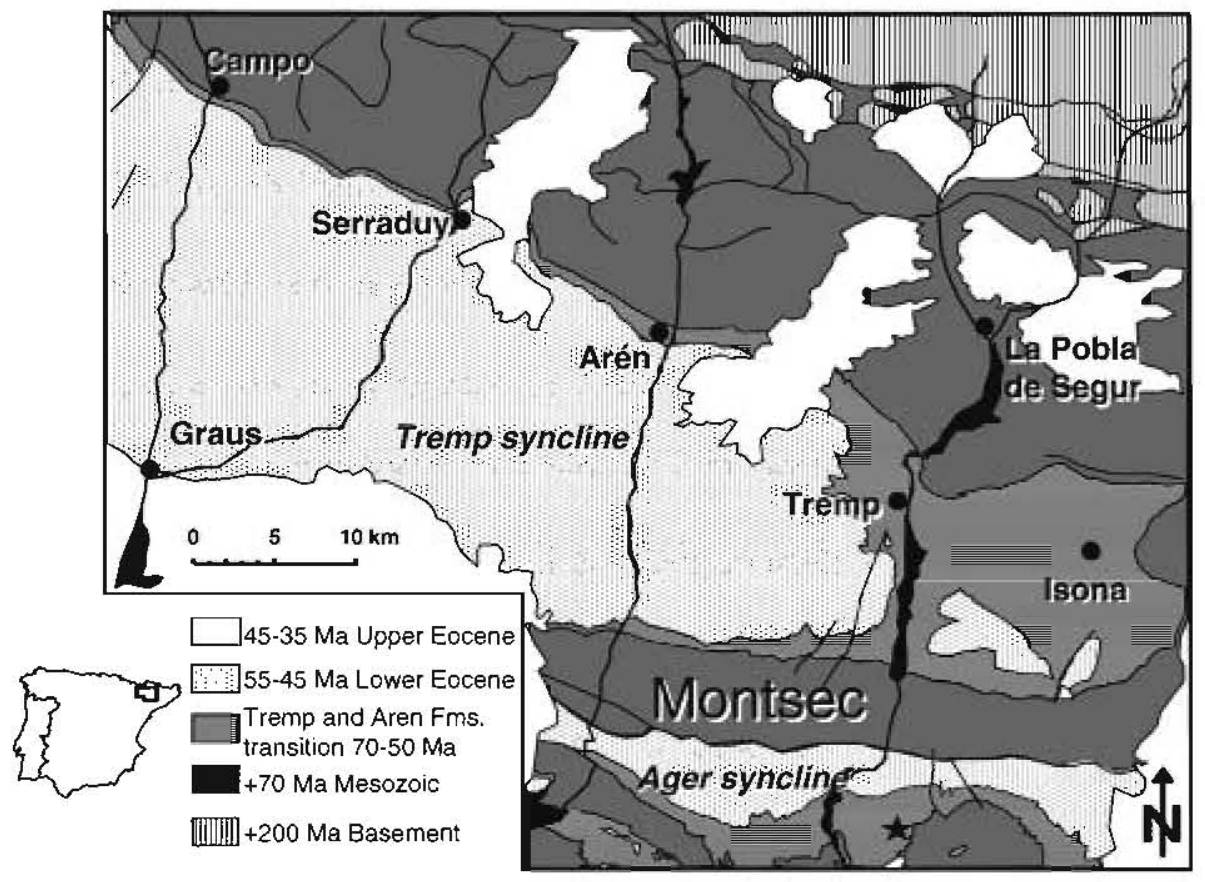

Fig. 1. Geological map of the studied area showing the location of the Fontllonga-3 site (black star). 


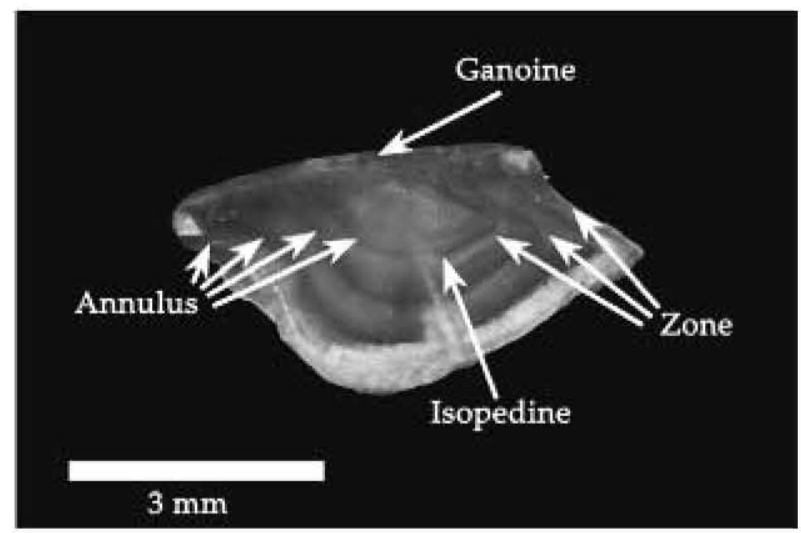

Fig. 2. Cross-section of a lepisosteid middle flank scale from the Fontllonga-3 site. Lepisosteid scales consist of two kinds of well differentiated tissues, known as ganoine and isopedine. Isopedine has three growth structures: zone, annulus and LAG (lines of arrested growth). LAG lines are not observed in this figure due to their reduced thickness.

The Fontllonga-3 locality is situated approximately $3 \mathrm{~m}$ above (a time span of 75-100 ky) the surface containing dinosaur footprints at Mas Morull and Sta. Maria de Meià (López-Martínez et al., 1999; Fernández-Marrón et al., 2004). The KTb occurs within a 1-3 $\mathrm{m}$ thick lutite interval near the top of the sandstone unit rich in dinosaur remains, although no iridium peak has been found yet at this location. The sampling of Fontllonga-3 has furnished a large number of fish bones, teeth and scales (Lepisosteiformes, Pycnodontiformes, Siluriformes and Osteoglosiformes; Soler-Gijón and López-Martínez, 2005) and some mammal teeth (the multituberculate Hainina; PeláezCampomanes et al., 2000). The appearance of Coelodus cf. laurenti, known in the Paleocene of the Paris Basin (Soler-Gijón and de la Peña, 1995) along with the Normapolles taxon Pseudoromeinipollenites paleocenicus (Kedves, 1982), the presence of a $\delta^{13} \mathrm{C}$ anomaly and the absence of dinosaur remains (not even as reworked fossils in contrast to the situation reported in the Western Interior Basin, USA) indicates an earliest Tertiary age (early Danian) for Fontllonga-3 (LópezMartínez et al., 1998).

\section{Lepisosteid scales}

The growth of lepisosteid scales are controlled by physiological variations and are related to environmental factors (climate and geography). As a result, the study of these types of scales could help to deduce environmental conditions (Iglesias Martin and SolerGijón, 1999). The scales consist of two kinds of well differentiated tissues, namely ganoine and isopedine (Fig. 2). The ganoine is developed in the basal layer of the epidermis and is a type of enamel with a pseudoprismatic structure (Sire, 1994; Schultze, 1996). The isopedine is formed in the interior of the dermis and is a laminar osseous cellular tissue (Thomson and McCune, 1984; Sire, 1994). The ganoine is discontinuously (periodically) deposited and is made up of successive layers deposited in alternation with the isopedine (that presents a more continuous growth). As a consequence, indentations can be observed at the interface between ganoine-isopedine. In the isopedine, three growth structures can be observed: zone, annulus and LAG (lines of arrested growth). The zone corresponds to the period of active growth of the fish which in turn, coincides with the favourable seasonal conditions and is characterized by a greater deposition of osseous tissue and a higher content of organic matter. The annulus corresponds to the period of the lowest physiological activity and thus indicates a reduction in growth. It is generated during unfavourable seasonal conditions and represents between $1 / 3$ and $1 / 4$ of the total breadth of the zone. Furthermore, it has a lower organic matter content when compared to the zone. The LAG corresponds to a total cessation in growth and may be due to physiological stress (reproduction, unfavourable environmental conditions, etc).

Grimes et al. (2003) analysed Late Eocene lepisosteid ganoine from the Hampshire Basin (United Kingdom) and argued that the isotopic results provided information about the temperature of the growing season. On the other hand, Fricke et al. (1998) carried out $\delta^{18} \mathrm{O}_{\mathrm{PO4}}$ analyses on Late Paleocene-Early Eocene Lepisosteus ganoine from the Bighorn Basin (Wyoming, USA) and claimed that since the ganoine is developed sequentially over the course of several years, $\delta^{18} \mathrm{O}_{\mathrm{PO4}}$ values represent a homogenized seasonal signal. Which of these two affirmations are correct needs to be tested with respect to the differentiation of the type of scale considered in each case.

Theoretically, based upon growth patterns recorded in extant relatives of lepisosteid fish the most propitious scales to conduct geochemical analyses on should be those from the central area of the fish body (Thomson and McCune, 1984; Sire, 1994) (Fig. 3), as scales from this region record the greatest number of layers of ganoine per unit of time and thus, the geochemical value furnished by these scales will correspond to the whole amplitude of the palaeoenvironmental and palaeoclimatic variations experienced during the life of the fish (for instance a complete annual cycle). The palaeotemperature record on the other hand should be more incomplete towards the dorsal area of the fish and above all, towards the posterior part. Finally, in the scales at the base of the caudal fin, the geochemical signal should only correspond to the maximum growing season (R. Soler-Gijón, pers. obs.).

\section{Material and methods}

The isolated lepisosteid scales from the Fontllonga-3 site (early Danian, Tremp Formation, South-Central Pyrenees, Spain) were first classified depending upon their shape, which can be used to determine their position on the fish body (Fig. 3). Ganoine and isopedine were then separated from each other by crushing individual scales and carefully picking both tissues under a binocular microscope. By employing a single genus, this study has tried to mitigate metabolic issues (vital effect) that may be present when making a comparison between different taxa.

The content of Rare Earth Elements (REEs) (La, Ce, Pr, Nd, Sm, Eu, Gd, Tb, Dy, Ho, Er, Yb, Lu) was examined in the lepisosteid ganoine and isopedine with the aim of detecting possible alterations due to diagenetic processes. According to Trueman (1999), elements La to Nd are defined as Light Rare Earth Elements (LREE), elements Sm to Dy are Middle Rare Earth Elements (MREE) and elements Tb to Lu are Heavy Rare Earth Elements (HREE). The concentration of REE is plotted relative to an international standard. PAAS values (Post-Archean Australian Shale of Taylor and McLennan, 1985) were used to normalize raw REE data in this study. The ganoine and isopedine were powdered and digested with $4 \mathrm{M} \mathrm{HNO}_{3}$ and REE results were obtained using an ICP-MS PlasmaQuad PQ2 + Turbo at the University of Plymouth (United Kingdom). The University of Plymouth laboratory standard $\mathrm{P} / \mathrm{N}$ 4400-130373 was used to calibrate the samples. The accuracy for each REE analysed is better than $5 \%$ of its concentration.

Ganoine $(n=25)$ and isopedine $(n=34)$ were also analysed for their $\mathrm{Ba} / \mathrm{Ca}$ and $\mathrm{Sr} / \mathrm{Ca}$ ratios. The ganoine was powdered, digested with $4 \mathrm{M} \mathrm{HNO}_{3}$, and diluted in ultra pure water up to $10 \mathrm{ml}$. Ba and $\mathrm{Sr}$ concentrations were determined by using an ICP-MS PlasmaQuad PQ2+ Turbo and $\mathrm{Ca}$ concentrations were measured by using an AAS Varian Spectr AA at the University of Plymouth. The international standard " 1400 Bone Ash" was used in accordance with protocol outlined by Balter and Lécuyer (2004). 


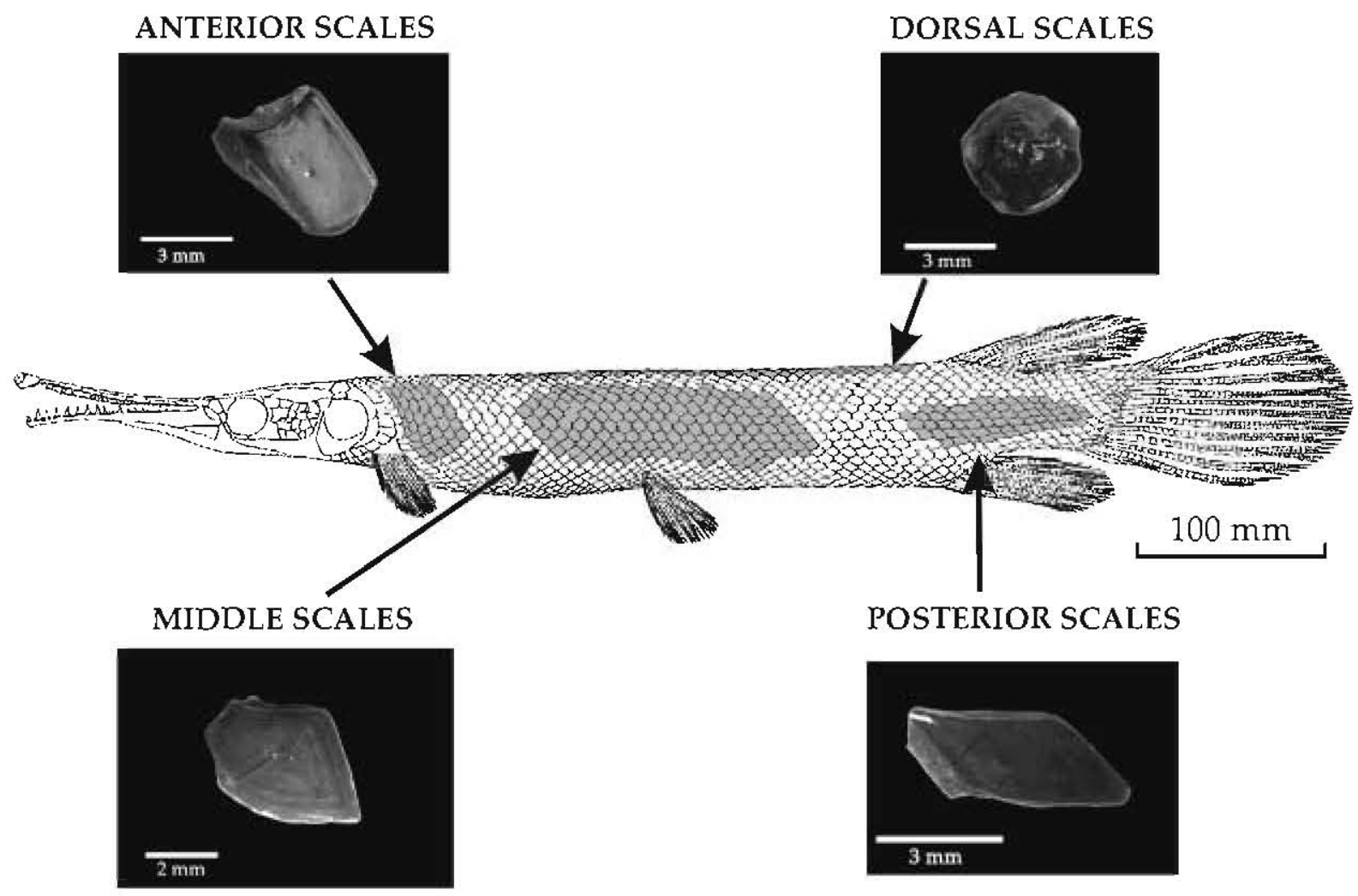

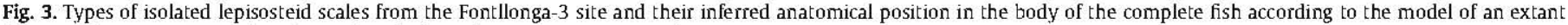
lepisosteiform, Lepisosteus platyrhincus (Gemballa and Bartsch, 2002: Fig. 2B).

Finally, 50 lepisosteid scales were measured for their $\delta^{18} \mathrm{O}_{\mathrm{PO} 4}$ values at Royal Holloway University of London (United Kingdom) using the direct laser fluorination (DLF) technique described by lindars et al. (2001) and modified by Grimes et al. (2003). This technique requires $\sim 2 \mathrm{mg}$ of sample. The pre-treatment of the samples involves heating the samples up to $400^{\circ} \mathrm{C}$ for $1 \mathrm{~h}$ and fusing under high vacuum in the sample chamber with the aim of removing all organic matter, $\mathrm{CO}_{3}^{2-}$ and $\mathrm{OH}^{-}$. The $\mathrm{CO}_{2}$ laser at $25 \mathrm{~W}$ produces a thermic reaction in presence of $\mathrm{BrF}_{5}$ which leads to the release of $100 \%$ oxygen from the remaining phosphate. The resulting $\delta^{18} \mathrm{O}_{\mathrm{PO4}}$ values were analysed by using a GVI Optima dual inlet mass spectrometer. The standard used was the NBS 120c Florida phosphate rock which gave a value of $21.13 \pm 0.51 \%$ (VSMOW) $(n=12)$.

\section{Results and discussion}

\subsection{Rare Earth Elements (REE)}

Reynard et al. (1999) and Lécuyer et al. (2003b) argued that the REE patterns could be indicative of the degree of diagenesis suffered by fossil bioapatite. A "bell shaped" REE pattern is due to extensive recrystallization of the apatite in the presence of REE-bearing fluids, meanwhile a flat REE profile indicates the absence of late diagenesis and recrystallization. The REE content of the lepisosteid scales from Fontllonga- 3 have been compared with vertebrate remains from the neighbouring Late Cretaceous sites (Laño, Uría and Cuezva, northern Spain; Lécuyer et al., 2003b, Fig. 4). The Laño samples display flat patterns, with 0.66 to $1.59(\mathrm{La} / \mathrm{Sm})_{\mathrm{N}}$ ratios and 1.03 to $3.12(\mathrm{Gd} / \mathrm{Yb})_{\mathrm{N}}$ ratios. Urría and Cuezva samples are characterized by "bell-shaped" patterns with low $(\mathrm{La} / \mathrm{Sm})_{\mathrm{N}}$ ratios $(0.03$ to 0.24$)$ and strong MREE enrichments indicated by $(\mathrm{Gd} / \mathrm{Yb})_{\mathrm{N}}$ ratios between 4.51 and 7.59 . Lepisosteid scales (ganoine and isopedine) from Fontllonga-3 display a flat REE pattern similar to Laño. Mean $(\mathrm{La} / \mathrm{Sm})_{\mathrm{N}}$ and $(\mathrm{Gd} / \mathrm{Yb})_{\mathrm{N}}$ values of 0.48 and 3.34 for the ganoine and 0.43 and 4.29 for the isopedine, are also similar in value to the vertebrate remains from Laño. This suggests a low degree of diagenesis for the Fontllonga-3 scales. It should also be noted that at Fontllonga-3, the ganoine has consistently lower REE concentrations compared to the isopedine, reflecting the higher resistance of this kind of tissue against post-burial alteration (Fig. 4).

Fig. 5 shows the position of mean ganoine and isopedine values for different types of lepisosteid scales from the Fontllonga- 3 site in a $(\mathrm{La} / \mathrm{Yb})_{\mathrm{N}}$ versus $(\mathrm{La} / \mathrm{Sm})_{\mathrm{N}}$ diagram proposed by Reynard et al. (1999) and modified by Lécuyer et al. (2003b). The samples from the Fontllonga-3 site are situated between estuarine and riverine environments. This interpretation of the depositional environment is in agreement with the sedimentological studies indicating upper estuarine conditions for the Unit 2 of the Tremp Formation (cf. LópezMartinez et al., 1998). In addition, it is noticeable that ganoine appears to reflect more faithfully the depositional environment compared to isopedine and hence, this fact provides evidence once more of a higher resistance of this kind of enamel.

\section{2. $\mathrm{Ba} / \mathrm{Ca}$ ratios, $\mathrm{Sr} / \mathrm{Ca}$ ratios and $\mathrm{Ba} / \mathrm{Ca}$ palaeotemperatures}

Wells et al. (2003) carried out a study of the variations in the $\mathrm{Ba} / \mathrm{Ca}$ and $\mathrm{Sr} / \mathrm{Ca}$ ratios in otoliths and scales of extant fish and proposed that there existed a correlation between the proportion of these ratios in the fish scales and otoliths and the geochemistry of the water they inhabited. Furthermore, these authors argued that it is preferable to choose juvenile specimens to assure that their geochemical sigual is not biased by late stage migration patterns and therefore, be more representative of the geochemical signal of the water in which they mainly lived. As a result of this potential bias, in Fontllonga-3 only scales of juvenile lepisosteid were selected for geochemical analyses. Table 1 and Fig. 6 show the $\mathrm{Ba} / \mathrm{Ca}$ and $\mathrm{Sr} / \mathrm{Ca}$ ratios measured on the ganoine and isopedine from different types of lepisosteid scales from the Fontllonga-3 site. It can be observed that there are no large differences 

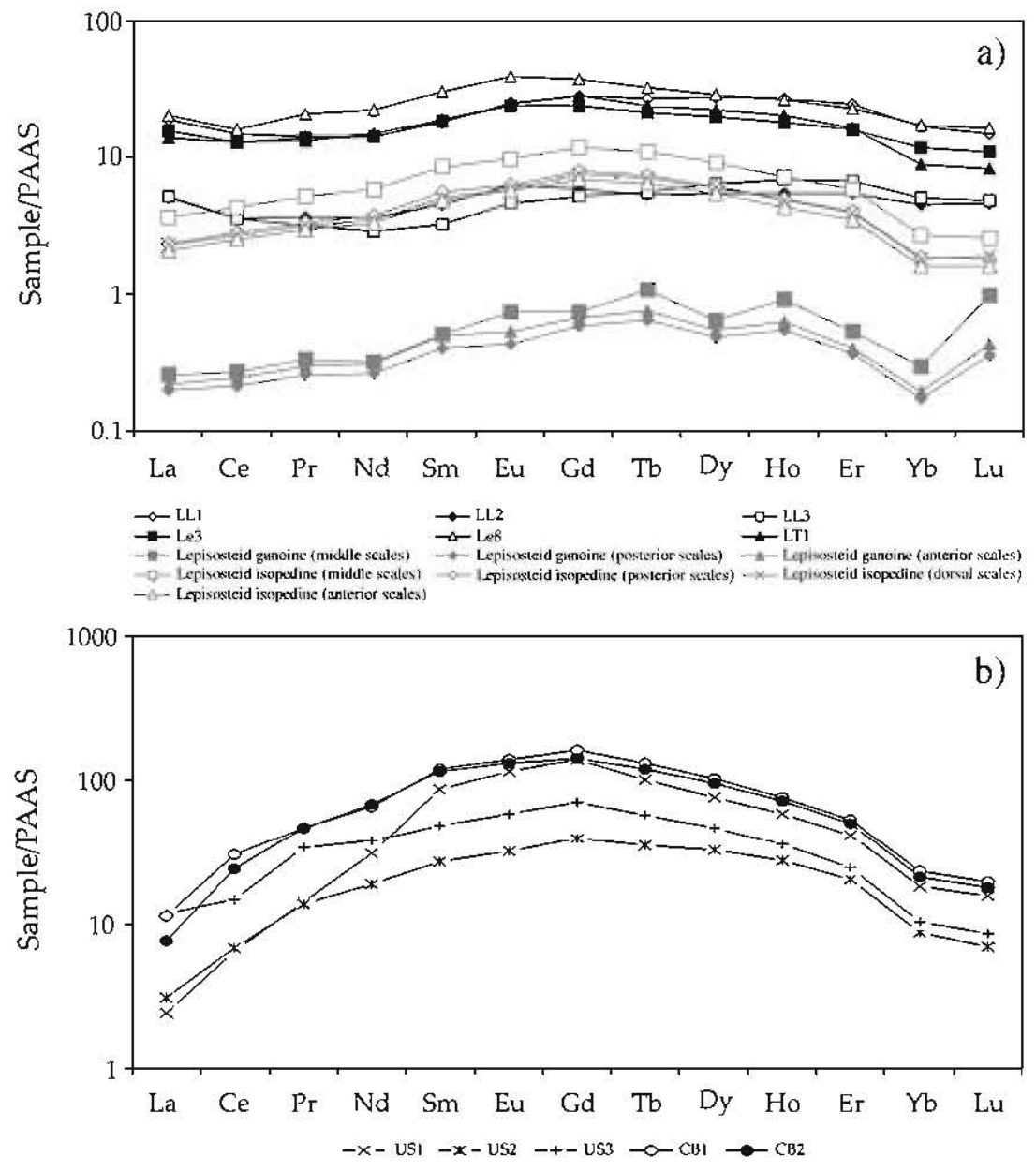

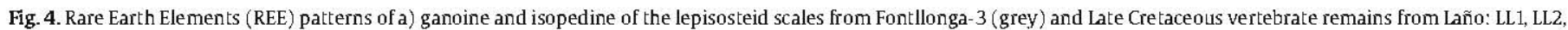

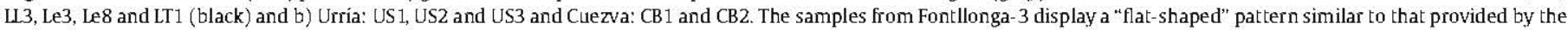

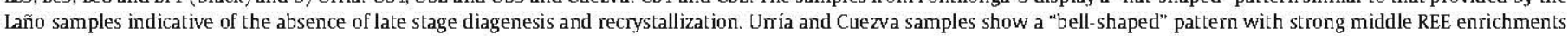

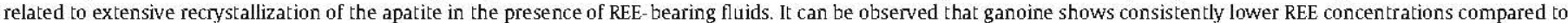

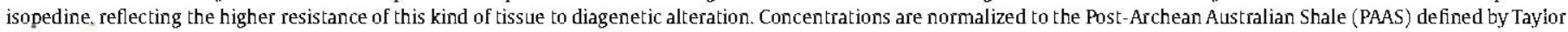
and MrLennan (1985). Data from Laño, Urria and Cuezva are from Lécuyer et al. (2003b).

in either $\mathrm{Ba} / \mathrm{Ca}$ or $\mathrm{Sr} / \mathrm{Ca}$ ratios among the different types of scales. In the case of the ganoine of the middle flank scales $(n=14)$, a mean Ba/Ca ratio of $0.25 \pm 0.11$ has been obtained with a corresponding $\mathrm{Sr} / \mathrm{Ca}$ ratio of $4.30 \pm 0.60$. As far as the ganoine of the posterior flank scales $(n=11), \mathrm{Ba} / \mathrm{Ca}$ and $\mathrm{Sr} / \mathrm{Ca}$ ratios of $0.28 \pm 0.20$ and $4.23 \pm 0.41$, respectively were obtained. There is a statistically significant difference between the $\mathrm{Ba} / \mathrm{Ca}$ ratio in the ganoine of these two types of scales, as reported through a Student $t$-test $(t=3.301, p=0.038)$, but not in the case of $\mathrm{Sr} / \mathrm{Ca}(t=0.311, p=0.758)$. The ganoine of one of the anterior flank scales analysed gives a $\mathrm{Ba} / \mathrm{Ca}$ ratio of 1.00 and a $\mathrm{Sr} / \mathrm{Ca}$ ratio of 4.37 .

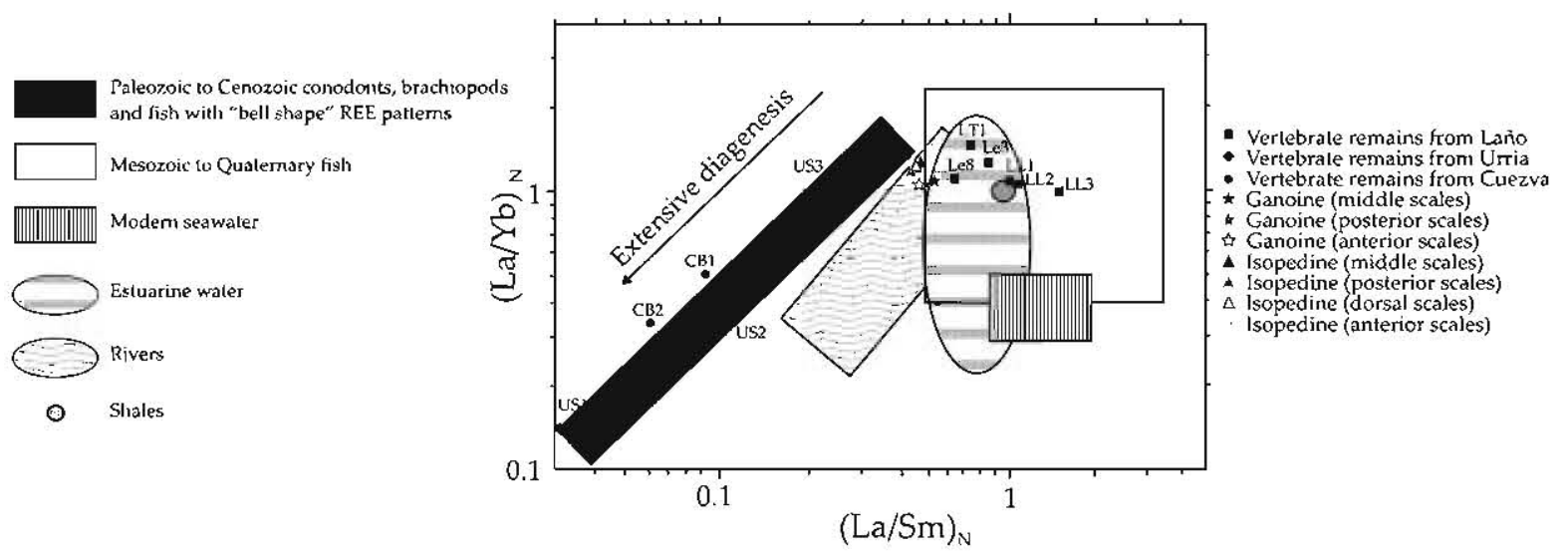

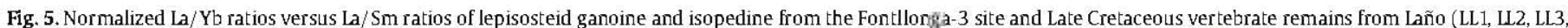

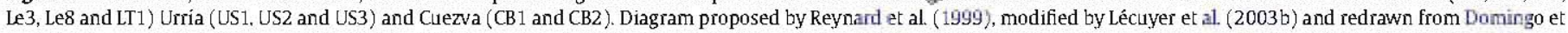

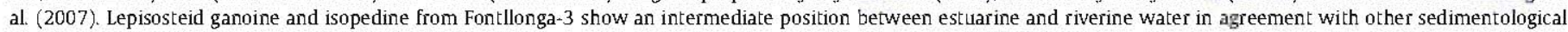
studies that indicate an upper estuarine environment for Unit 2 of the Tremp Formation (López-Martínez et al., 1998). 
Table 1

Sr, Ba, Ca concentrations, Ba/Ca, Sr/Ca rati

\begin{tabular}{|c|c|c|c|c|c|c|c|c|c|c|c|c|}
\hline Tissue-position & Signature & $\begin{array}{l}\mathrm{Ba} \\
(\mu \mathrm{g} / \mathrm{g})\end{array}$ & $\begin{array}{l}\mathrm{Sr} \\
(\mu \mathrm{g} / \mathrm{g})\end{array}$ & $\begin{array}{l}\mathrm{Ca} \\
(\mu \mathrm{g} / \mathrm{g})\end{array}$ & $\begin{array}{l}\mathrm{Ba} / \\
\mathrm{Ca}\end{array}$ & $\begin{array}{l}\mathrm{Sr} / \\
\mathrm{Ca}\end{array}$ & $\begin{array}{l}T^{1} \\
\left({ }^{\circ} \mathrm{C}\right)\end{array}$ & $\begin{array}{l}\text { Mean } T \pm 1 S D^{1} \\
\left({ }^{\circ} \mathrm{C}\right)\end{array}$ & $\begin{array}{l}\mathrm{T}^{2} \\
\left({ }^{\circ} \mathrm{C}\right)\end{array}$ & $\begin{array}{l}\text { Mean } T \pm 1 S D^{2} \\
\left({ }^{\circ} \mathrm{C}\right)\end{array}$ & $\begin{array}{l}\mathrm{T}^{3} \\
\left({ }^{\circ} \mathrm{C}\right)\end{array}$ & $\begin{array}{l}\text { Mean } T \pm 1 S^{2} \\
\left({ }^{\circ} \mathrm{C}\right)\end{array}$ \\
\hline \multirow[t]{14}{*}{ Ganoine-middle scale } & FONT 3-07-CG-2 & 112.41 & 1531.03 & $393,103.45$ & 0.29 & 3.89 & 21.90 & \multirow[t]{14}{*}{$24.97 \pm 6.11$} & 29.93 & \multirow[t]{14}{*}{$33.77 \pm 7.02$} & 35.89 & \multirow[t]{14}{*}{$39.89 \pm 7.30$} \\
\hline & FONT 3-07-CG-4 & 82.95 & 1744.19 & $395,348.84$ & 0.21 & 4.41 & 27.99 & & 36.36 & & 42.58 & \\
\hline & FONT 3-07-CG-5 & 238.10 & 1666.67 & $412,698.41$ & 0.58 & 4.04 & 8.97 & & 16.30 & & 21.73 & \\
\hline & FONT 3-07-CG-6 & 74.67 & 1526.67 & $398,333.33$ & 0.19 & 3.83 & 30.27 & & 38.76 & & 45.09 & \\
\hline & FONT 3-07-CG-8 & 110.05 & 1629.63 & $439,153.44$ & 0.25 & 3.71 & 24.47 & & 32.63 & & 38.71 & \\
\hline & FONT 3-07-CG-10 & 103.06 & 2070.59 & $407,303.37$ & 0.25 & 5.08 & 24.28 & & 32.44 & & 38.50 & \\
\hline & FONT 3-07-CG-11' & 86.98 & 1815.13 & $434,873.95$ & 0.20 & 4.17 & 27.66 & & 37.07 & & 43.32 & \\
\hline & FONT 3-07-CG-13 & 136.61 & 2535.71 & $430,803.57$ & 0.32 & 5.89 & 19.92 & & 27.84 & & 33.72 & \\
\hline & FONT 3-07-CG-15' & 71.49 & 1711.11 & $397,222.22$ & 0.18 & 4.31 & 28.64 & & 39.16 & & 45.50 & \\
\hline & FONT 3-07-CG-20 & 140.52 & 1706.90 & $422,413.79$ & 0.33 & 4.04 & 19.01 & & 26.88 & & 32.73 & \\
\hline & FONT 3-07-CG-21' & 82.40 & 1548.00 & $412,000.00$ & 0.20 & 3.76 & 27.86 & & 37.27 & & 43.53 & \\
\hline & FONT 3-07-CG-22' & 64.83 & 1838.71 & $405,241.94$ & 0.16 & 4.54 & 31.20 & & 41.86 & & 48.31 & \\
\hline & FONT 3-07-CG-23' & 62.87 & 1622.75 & $419,161.68$ & 0.15 & 3.87 & 32.29 & & 43.02 & & 49.51 & \\
\hline & FONT 3-07-CG-24 & 105.84 & 2021.90 & $436,131.39$ & 0.24 & 4.64 & 25.10 & & 33.30 & & 39.40 & \\
\hline \multirow[t]{11}{*}{ Ganoine-posterior scale } & FONT 3-07-PG-2 & 72.73 & 1539.39 & $439,393.94$ & 0.17 & 3.50 & 32.83 & \multirow[t]{11}{*}{$29.49 \pm 4.15$} & 41.47 & \multirow[t]{11}{*}{$34.11 \pm 5.63$} & 47.90 & \multirow[t]{11}{*}{$40.25 \pm 5.76$} \\
\hline & FONT 3-07-PG-4 & 256.28 & 1604.65 & $404,651.16$ & 0.63 & 3.97 & 27.34 & & 14.58 & & 19.95 & \\
\hline & FONT 3-07-PG-7 & 92.64 & 1580.09 & $385,281.39$ & 0.24 & 4.10 & 25.28 & & 33.49 & & 39.60 & \\
\hline & FONT 3-07-PG-8 & 71.55 & 1824.74 & $461,340.21$ & 0.16 & 3.96 & 34.18 & & 42.90 & & 49.39 & \\
\hline & FONT 3-07-PG-9 & 288.59 & 1684.56 & $390,939.60$ & 0.74 & 4.31 & 24.69 & & 11.80 & & 17.06 & \\
\hline & FONT 3-07-PG- 13 & 66.97 & 1517.24 & $374,137.93$ & 0.18 & 4.06 & 31.21 & & 39.76 & & 46.13 & \\
\hline & FONT 3-07-PG-17 & 81.16 & 1947.37 & $457,894.74$ & 0.18 & 4.25 & 31.42 & & 39.98 & & 46.35 & \\
\hline & FONT 3-07-PG-18 & 90.52 & 1822.92 & $447,916.67$ & 0.20 & 4.07 & 28.74 & & 37.15 & & 43.41 & \\
\hline & FONT 3-07-PG-20 & 70.19 & 2102.80 & $441,588.79$ & 0.16 & 4.76 & 33.67 & & 42.36 & & 48.83 & \\
\hline & FONT 3-07-PG-21 & 62.44 & 1822.22 & $381,481.48$ & 0.16 & 4.78 & 33.06 & & 41.71 & & 48.15 & \\
\hline & FONT 3-07-PG-23 & 120.27 & 2027.03 & $422,297.30$ & 0.28 & 4.80 & 21.98 & & 30.01 & & 35.98 & \\
\hline \multirow[t]{13}{*}{ Isopedine-middle scale } & FONT 3-07-CI-1 & 108.04 & 1589.81 & $367,292.23$ & 0.29 & 4.33 & 21.36 & \multirow{13}{*}{$19.20 \pm 5.73$} & 29.35 & \multirow[t]{13}{*}{$27.09 \pm 6.05$} & 35.29 & \multirow[t]{13}{*}{$32.94 \pm 6.28$} \\
\hline & FONT 3-07-CI-2 & 118.64 & 1644.07 & $367,231.64$ & 0.32 & 4.48 & 19.57 & & 27.47 & & 33.33 & \\
\hline & FONT 3-07-CI-3 & 129.66 & 1634.48 & $332,758.62$ & 0.39 & 4.91 & 16.06 & & 23.76 & & 29.49 & \\
\hline & FONT 3-07-CI-4 & 95.35 & 1656.57 & $331,313.13$ & 0.29 & 5.00 & 21.78 & & 29.80 & & 35.76 & \\
\hline & FONT 3-07-CI-6 & 77.53 & 1820.22 & $365,168.54$ & 0.21 & 4.98 & 27.75 & & 36.11 & & 42.32 & \\
\hline & FONT 3-07-CI-7 & 111.19 & 1828.36 & $350,746.27$ & 0.32 & 5.21 & 19.93 & & 27.84 & & 33.73 & \\
\hline & FONT 3-07-CI-9 & 94.66 & 1916.03 & $381,679.39$ & 0.25 & 5.02 & 24.67 & & 32.85 & & 38.93 & \\
\hline & FONT 3-07-CI-10 & 198.41 & 1952.38 & $361,111.11$ & 0.55 & 5.41 & 9.83 & & 17.21 & & 22.68 & \\
\hline & FONT 3-07-CI-11 & 96.81 & 1792.55 & $353,723.40$ & 0.27 & 5.07 & 22.75 & & 30.82 & & 36.82 & \\
\hline & FONT 3-07-CI-12 & 76.51 & 1924.77 & $308,256.88$ & 0.25 & 6.24 & 24.65 & & 32.83 & & 38.91 & \\
\hline & FONT 3-07-CI-15 & 122.22 & 1976.19 & $357,142.86$ & 0.34 & 5.53 & 18.48 & & 26.32 & & 32.14 & \\
\hline & FONT 3-07-CI-17 & 176.80 & 1728.76 & $415,032.68$ & 0.43 & 4.17 & 14.42 & & 22.03 & & 27.69 & \\
\hline & FONT 3-07-CI-24 & 213.68 & 1863.25 & $358,974.36$ & 0.60 & 5.19 & 8.42 & & 15.72 & & 21.13 & \\
\hline \multirow[t]{13}{*}{ Isopedine-posterior scale } & FONT 3-07-PI-1 & 102.92 & 1883.21 & $374,087.59$ & 0.28 & 5.03 & 22.65 & $22.69 \pm 4.09$ & 30.71 & $30.76 \pm 4.31$ & 36.71 & $36.76 \pm 4.49$ \\
\hline & FONT 3-07-PI-2 & 122.70 & 1840.49 & $407,975.46$ & 0.30 & 4.51 & 20.93 & & 28.90 & & 34.83 & \\
\hline & FONT 3-07-PI-3 & 97.62 & 1904.76 & $384,920.63$ & 0.25 & 4.95 & 24.23 & & 32.39 & & 38.45 & \\
\hline & FONT 3-07-PI-4 & 96.21 & 1947.37 & $410,526.32$ & 0.23 & 4.74 & 25.79 & & 34.03 & & 40.16 & \\
\hline & FONT 3-07-PI-5 & 112.82 & 1647.89 & $352,112.68$ & 0.32 & 4.68 & 19.73 & & 27.63 & & 33.51 & \\
\hline & FONT 3-07-PI-6 & 117.94 & 1641.26 & $417,040.36$ & 0.28 & 3.94 & 22.12 & & 30.15 & & 36.13 & \\
\hline & FONT 3-07-PI-7 & 85.82 & 1957.45 & 462.719 .30 & 0.19 & 4.23 & 30.49 & & 38.99 & & 45.33 & \\
\hline & FONT 3-07-PI-8 & 99.39 & 1926.38 & $420,245.40$ & 0.24 & 4.58 & 25.61 & & 33.84 & & 39.96 & \\
\hline & FONT 3-07-PI- 11 & 125.41 & 1983.61 & $344,262.30$ & 0.36 & 5.76 & 17.31 & & 25.08 & & 30.86 & \\
\hline & FONT 3-07-PI- 12 & 89.66 & 1939.66 & $381,465.52$ & 0.24 & 5.08 & 25.73 & & 33.97 & & 40.09 & \\
\hline & FONT 3-07-PI-15 & 139.81 & 2398.15 & $328,703.70$ & 0.43 & 7.30 & 14.44 & & 22.06 & & 27.72 & \\
\hline & FONT 3-07-PI-17 & 112.50 & 2244.79 & $403,645.83$ & 0.28 & 5.56 & 22.40 & & 30.45 & & 36.44 & \\
\hline & FONT 3-07-PI-24 & 88.99 & 1902.14 & $339,449.54$ & 0.26 & 5.60 & 23.58 & & 31.70 & & 37.74 & \\
\hline Isopedine-anterior scale & FONT 3-07-AI-1 & 91.80 & 1846.99 & $371,584.70$ & 0.25 & 4.97 & 24.75 & $21.84 \pm 2.62$ & 32.93 & $29.86 \pm 2.76$ & 39.01 & $35.82 \pm 2.87$ \\
\hline & FONT 3-07-AI-3 & 112.64 & 1678.16 & $350,574.71$ & 0.32 & 4.79 & 19.67 & & 27.58 & & 33.45 & \\
\hline & FONT 3-07-AI-5 & 106.67 & 1842.42 & $357,575.76$ & 0.30 & 5.15 & 21.09 & & 29.07 & & 35.00 & \\
\hline Isopedine-dorsal scale & FONT 3-07-DVI-1 & 160.81 & 2013.51 & $378,378.38$ & 0.43 & 5.32 & 14.46 & $19.08 \pm 6.29$ & 22.08 & $26.95 \pm 6.64$ & 27.74 & $32.80 \pm 6.90$ \\
\hline & FONT 3-07-DVI-2 & 92.63 & 1984.21 & $371,052.63$ & 0.25 & 5.35 & 24.54 & & 32.71 & & 38.79 & \\
\hline & FONT 3-07-DVI-3 & 178.23 & 1691.39 & $385,167.46$ & 0.46 & 4.39 & 12.91 & & 20.45 & & 26.04 & \\
\hline & FONT 3-07-DVI-4 & 76.80 & 1712.71 & $348,066.30$ & 0.22 & 4.92 & 26.98 & & 35.29 & & 41.47 & \\
\hline & FONT 3-07-DVI-5 & 141.60 & 1744.00 & $372,000.00$ & 0.38 & 4.69 & 16.49 & & 24.22 & & 29.96 & \\
\hline
\end{tabular}

The palaeotemperatures were calculated using the $\mathrm{Ba} / \mathrm{Ca}$ thermometry equation (Eq. (1)) of Balter and Lécuyer (2004).

1 Palaeotemperature values calculated when using a Ba/Ca ratio for the water of 0.0010 .

2 Palaeotemperat ure values calculated when using a Ba/Ca ratio for the water of 0.0015 .

3 Palaeotemperature values calculated when using a Ba/Ca ratio for the water of 0.0020 .

In the case of the isopedine, the middle flank scales $(n=13)$ provide a Ba/Ca ratio of $0.35 \pm 0.11$ and a Sr/Ca ratio of $5.04 \pm 0.54$. Posterior flank scales $(n=13)$ show $\mathrm{Ba} / \mathrm{Ca}$ and $\mathrm{Sr} / \mathrm{Ca}$ values of $0.28 \pm 0.20$ and $5.07 \pm 0.86$, respectively. In a similar manner to the ganoine, a statistically significant difference can be observed in the case of $\mathrm{Ba} / \mathrm{Ca}$ in the isopedine $(\mathrm{t}=3.489, p=0.035)$, but not in the case of $\mathrm{Sr} / \mathrm{Ca}(\mathrm{t}=$ $-0.115, p=0.909$ ). The isopedine of the anterior flank scales $(n=3)$ gives a Ba/Ca ratio of $0.29 \pm 0.04$ and $\mathrm{S} / \mathrm{Ca}$ ratio of $4.97 \pm 0.18$. Finally, the dorsal scales $(n=5)$ give ratios of $0.35 \pm 0.11$ and $4.93 \pm 0.41$ respectively for $\mathrm{Ba} / \mathrm{Ca}$ and $\mathrm{Sr} / \mathrm{Ca}$.

The analysis of variance (ANOVA) has not detected any significant differences in $\mathrm{Ba} / \mathrm{Ca}$ and $\mathrm{Sr} / \mathrm{Ca}$ ratios among the different types of scales when comparing ganoine and isopedine $(F=1.439, p=0.219$ in the case of $\mathrm{Ba} / \mathrm{Ca}$ ratio and $F=1.354, p=0.251$ in the case of $\mathrm{Sr} / \mathrm{Ca}$ 


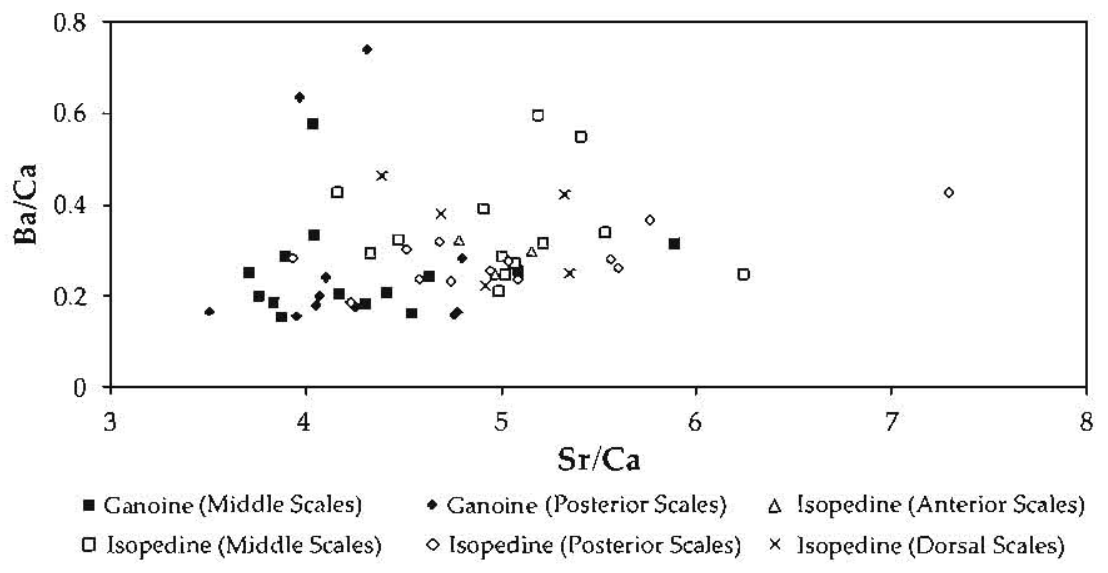

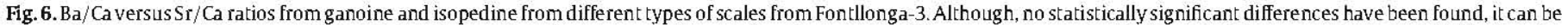

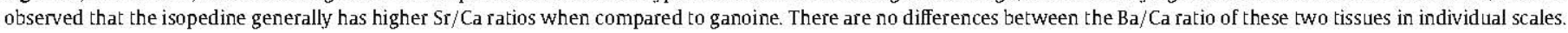

ratio). Although, no significant differences have been pinpointed, it can be observed in Fig. 6 that the isopedine gives higher $\mathrm{Sr} / \mathrm{Ca}$ values when compared to the ganoine. This may be related to a greater incorporation of $\mathrm{Sr}$ by the isopedine during the fossilization process. There are no differences between the $\mathrm{Ba} / \mathrm{Ca}$ values of the ganoine and the isopedine from individual scales.

Palaeotemperatures have been calculated using the $\mathrm{Ba} / \mathrm{Ca}$ thermometry method outlined by Balter and Lécuyer (2004). According to these authors, the thermodependence of $\mathrm{Ba}$ partitioning between apatite and water at low temperature could be obtained by using the following equation (Eq. (1)):

$\log \left(K_{\text {aparite-warer }}^{\mathrm{Ba} / \mathrm{a}}\right)=1.96 \pm 0.06\left(10^{3} T^{-1}\right)-7.19 \pm 0.20\left(r^{2}=0.99\right)(1)$

where $K_{\text {apatite-water }}^{\mathrm{Ba}}=(\mathrm{Ba} / \mathrm{Ca})_{\text {apatite }} /(\mathrm{Ba} / \mathrm{Ca})_{\text {water }}$ and $T$ is the temperature in Kelvin. Although Balter and Lécuyer (2004) derived this palaeothermometer by using inorganically precipitated apatite, they demonstrated its validity by calculating palaeotemperatures from fish teeth across the KTb in Morocco which mirrored those calculated using another established palaeothermometer. The mean $\mathrm{Ba} / \mathrm{Ca}$ ratio of the water from which the ganoine and isopedine was precipitated is a component of this thermometry equation. In the study of Balter and Lécuyer (2004) they used a seawater ratio of 0.0010. In this study, determining this initial ratio is more difficult since estuarine conditions have been suggested for the Fontllonga-3 site. Due to constant changing conditions in estuarine waters, $\mathrm{Ba} / \mathrm{Ca}$ values show some extent of variability and on account of this, several authors have tried to determine the relationship between the $\mathrm{Ba} / \mathrm{Ca}$ content in scales and otoliths and that in different types of aquatic environments (Wells et al, 2000; Elsdon and Gillanders, 2003, 2005, 2006). Elsdon and Gillanders (2005) argued that black bream fish caught in freshwater had $\mathrm{Ba} / \mathrm{Ca}$ ratios in their otoliths which were double that found in fish from salt-water estuaries. On the other hand, wells et al. (2000) carried out a study of trace elements in modern juvenile spots and found a linear relationship between the $\mathrm{Ba} / \mathrm{Ca}$ content in otoliths and scales and the water in which they lived. Based upon these modern studies, in addition to a marine $\mathrm{Ba} / \mathrm{Ca}$ ratio of 0.0010 , a Ba/Ca ratio of 0.0020 will be considered suitable for riverine conditions, whereas an intermediate value of 0.0015 will be regarded as representative of an estuarine environment. It is necessary to stress, however, that some degree of uncertainty will always remain as far as the true $\mathrm{Ba} / \mathrm{Ca}$ ratio in the estuarine waters around the Fontllonga-3 site are concerned.

Nevertheless, regardless of which initial $\mathrm{Ba} / \mathrm{Ca}$ value is used, our results in Table 1 show that in general the ganoine records higher temperatures than the isopedine. The ganoine of the middle flank scales provides mean temperature values of $24.97 \pm 6.11{ }^{\circ} \mathrm{C}, 33.77 \pm 7.02{ }^{\circ} \mathrm{C}$ and $39.89 \pm 7.30^{\circ} \mathrm{C}$ when applying $\mathrm{Ba} / \mathrm{Ca}$ values for the water of 0.0010 , 0.0015 and 0.0020 , respectively; meanwhile, the ganoine of the posterior flank scales fumishes mean values of $29.49 \pm 4.15^{\circ} \mathrm{C}, 34.11 \pm$ $5.63{ }^{\circ} \mathrm{C}$ and $40.25 \pm 5.76{ }^{\circ} \mathrm{C}$. The isopedine of the middle flank scales records mean temperature values of $19.20 \pm 5.73^{\circ} \mathrm{C}, 27.09 \pm 6.05^{\circ} \mathrm{C}$ and $32.94 \pm 6.28{ }^{\circ} \mathrm{C}$, whereas in the posterior flank scales, this tissue provides values of $22.69 \pm 4.09{ }^{\circ} \mathrm{C}, 30.76 \pm 4.31{ }^{\circ} \mathrm{C}, 36.76 \pm 4.49{ }^{\circ} \mathrm{C}$. The isopedine of the anterior flank scales presents temperature values of $21.84 \pm 2.62{ }^{\circ} \mathrm{C}, 29.86 \pm 2.76{ }^{\circ} \mathrm{C}$ and $35.82 \pm 2.87{ }^{\circ} \mathrm{C}$. Finally, the isopedine of the dorsal scales furnishes values of $19.08 \pm 6.29{ }^{\circ} \mathrm{C}$, $26.95 \pm 6.64{ }^{\circ} \mathrm{C}$ and $32.80 \pm 6.90{ }^{\circ} \mathrm{C}$.

The ganoine $\mathrm{Ba} / \mathrm{Ca}$ palaeotemperatures calculated when using an initial $\mathrm{Ba} / \mathrm{Ca}$ ratio of 0.0010 are in line with the range of temperature of the water in which extant relatives of osteoglossiform fish (whose remains have been found in Fontllonga- 3 along with lepisosteid remains) inhabit nowadays $\left(24-40^{\circ} \mathrm{C}\right.$, with mean values of 27 to $32^{\circ} \mathrm{C}$; Froese and Pauly, 2008). Temperature values calculated when using $\mathrm{Ba} / \mathrm{Ca}$ water values of 0.0015 and 0.0020 (hypothetical estuarine and riverine waters, respectively) are significantly higher and do not resemble values provided by the $\delta^{18} \mathrm{O}_{\mathrm{PO4}}$ palaeothermometer (see next section).

The $\mathrm{Ba} / \mathrm{Ca}$ ratio recorded in fish otoliths, scales and bones is related to the level of dissolved barium available in the aquatic habitat (Milton et al., 2008 and references therein). Rivers constitute the main source of barium to estuaries. Elevated dissolved barium concentrations appear in the mixing zone of estuaries where suspended fluvial sediment releases barium in exchange for the cations of the seawater (Li and Chan, 1979; Carroll et al., 1993; Coffey et al., 1997; Nozaki et al., 2001; Colbert and McManus, 2005). That peak of barium usually takes place at low salinity. However, an important removal of dissolved barium at reduced salinities has been also reported in several estuaries (see Fig. 6 in Coffey et al., 1997, evidence by bell-shaped profiles in the barium concentration versus salinity plots).

The geochemical signature recorded in the ganoid scales from the Fontllonga-3 site suggests that juvenile lepisosteids were living far from the area where the maximum release of barium occurred. This is in agreement with the interpretation of Fontllonga- 3 as a deposit of oxbow lake. The waters of the Fontllonga- 3 oxbow lake (fresh to oligohaline) were temporally isolated from the river main stream or did not vary their salinity by tidal influence. Interestingly, juveniles of extant lepisosteiformes are frequently found in oxbow lakes and usually remain in these areas for long periods even when the connection with the river is restored (Robertson et al., 2008).

\section{3. $\delta^{18} \mathrm{O}_{\mathrm{PO4}}$ results and palaeotemperatures}

$\delta^{18} \mathrm{O}_{\mathrm{PO4}}$ analyses on fossil lepisosteid scales (specifically ganoine) have widely been used with the aim of gaining information about 
Table 2

${ }^{18} \mathrm{O}_{\mathrm{PO} 4}$ and minimum, maximum and mean palaeotemperature values applying Kolodny et al.'s (1983) equation (Eq. (2)).

\begin{tabular}{|c|c|c|c|c|c|c|}
\hline Tissue-position & Signature & $\begin{array}{l}{ }^{18} \mathrm{O}_{\mathrm{PO} 4} \\
\text { (\%VSMOW) }\end{array}$ & $\begin{array}{l}\operatorname{Min} T \\
\left({ }^{\circ} \mathrm{C}\right)\end{array}$ & $\begin{array}{l}\operatorname{Max} T \\
\left({ }^{\circ} \mathrm{C}\right)\end{array}$ & $\begin{array}{l}\text { Mean } T \\
\left({ }^{\circ} \mathrm{C}\right)\end{array}$ & $\begin{array}{l}\text { Mean value } T \pm 1 \text { SD } \\
\left({ }^{\circ} \mathrm{C}\right)\end{array}$ \\
\hline \multirow[t]{20}{*}{ Ganoine-middle scale } & FONT 3-07-CG-1 & 17.65 & 18.43 & 31.83 & 25.13 & $29.05 \pm 4.04$ \\
\hline & FONT 3-07-CG-2 & 15.64 & 27.25 & 40.65 & 33.95 & \\
\hline & FONT 3-07-CG-3 & 16.49 & 23.51 & 36.91 & 30.21 & \\
\hline & FONT 3-07-CG-4 & 15.74 & 26.80 & 40.20 & 33.50 & \\
\hline & FONT 3-07-CG-5 & 18.23 & 15.91 & 29.31 & 22.61 & \\
\hline & FONT 3-07-CG-6 & 16.89 & 21.75 & 35.15 & 28.45 & \\
\hline & FONT 3-07-CG-7 & 17.57 & 18.79 & 32.19 & 25.49 & \\
\hline & FONT 3-07-CG-8 & 14.89 & 30.54 & 43.94 & 37.24 & \\
\hline & FONT 3-07-CG-9 & 15.31 & 28.68 & 42.08 & 35.38 & \\
\hline & FONT 3-07-CG-10 & 17.07 & 20.99 & 34.39 & 27.69 & \\
\hline & FONT 3-07-CG-11 & 17.54 & 18.91 & 32.32 & 25.62 & \\
\hline & FONT 3-07-CG-12 & 16.20 & 24.77 & 38.17 & 31.47 & \\
\hline & FONT 3-07-CG-13 & 17.16 & 20.58 & 33.98 & 27.28 & \\
\hline & FONT 3-07-CG-14 & 16.55 & 23.25 & 36.65 & 29.95 & \\
\hline & FONT 3-07-CG-15 & 18.15 & 16.24 & 29.64 & 22.94 & \\
\hline & FONT 3-07-CG-16 & 16.28 & 24.42 & 37.82 & 31.12 & \\
\hline & FONT 3-07-CG-17 & 16.55 & 23.26 & 36.66 & 29.96 & \\
\hline & FONT 3-07-CG-18 & 16.56 & 23.19 & 36.59 & 29.89 & \\
\hline & FONT 3-07-CG-19 & 17.79 & 17.82 & 31.22 & 24.52 & \\
\hline & FONT 3-07-CG-20 & 16.85 & 21.94 & 35.34 & 28.64 & \\
\hline \multirow[t]{19}{*}{ Ganoine-posterior scale } & FONT 3-07-PG-1 & 16.65 & 22.83 & 36.23 & 29.53 & $30.53 \pm 3.28$ \\
\hline & FONT 3-07-PG-2 & 16.53 & 23.34 & 36.74 & 30.04 & \\
\hline & FONT 3-07-PG-3 & 15.32 & 28.63 & 42.04 & 35.34 & \\
\hline & FONT 3-07-PG-4 & 16.65 & 22.83 & 36.23 & 29.53 & \\
\hline & FONT 3-07-PG-5 & 15.36 & 28.46 & 41.86 & 35.16 & \\
\hline & FONT 3-07-PG-6 & 15.85 & 26.34 & 39.74 & 33.04 & \\
\hline & FONT 3-07-PG-7 & 15.07 & 29.71 & 43.12 & 36.41 & \\
\hline & FONT 3-07-PG-8 & 17.23 & 20.26 & 33.66 & 26.96 & \\
\hline & FONT 3-07-PG-10 & 17.59 & 18.69 & 32.09 & 25.39 & \\
\hline & FONT 3-07-PG-11 & 15.72 & 26.88 & 40.29 & 33.58 & \\
\hline & FONT 3-07-PG-12 & 17.19 & 20.43 & 33.83 & 27.13 & \\
\hline & FONT 3-07-PG-13 & 16.31 & 24.28 & 37.68 & 30.98 & \\
\hline & FONT 3-07-PG-14 & 16.57 & 23.15 & 36.55 & 29.85 & \\
\hline & FONT 3-07-PG-15 & 16.11 & 25.16 & 38.56 & 31.86 & \\
\hline & FONT 3-07-PG-16 & 17.85 & 17.53 & 30.94 & 24.24 & \\
\hline & FONT 3-07-PG-17 & 16.68 & 22.69 & 36.09 & 29.39 & \\
\hline & FONT 3-07-PG-18 & 16.56 & 23.20 & 36.60 & 29.90 & \\
\hline & FONT 3-07-PG-19 & 16.56 & 23.20 & 36.61 & 29.90 & \\
\hline & FONT 3-07-PG-20 & 16.13 & 25.09 & 38.49 & 31.79 & \\
\hline \multirow[t]{6}{*}{ Ganoine-anterior scale } & FONT 3-07-AG-1 & 16.68 & 22.68 & 36.08 & 29.38 & $27.87 \pm 3.57$ \\
\hline & FONT 3-07-AG-2 & 16.23 & 24.67 & 38.07 & 31.37 & \\
\hline & FONT 3-07-AG-3 & 17.23 & 20.27 & 33.67 & 26.97 & \\
\hline & FONT 3-07-AG-4 & 16.65 & 22.81 & 36.21 & 29.51 & \\
\hline & FONT 3-07-AG-5 & 18.55 & 14.49 & 27.89 & 21.19 & \\
\hline & FONT 3-07 AG-9 & 16.81 & 22.11 & 35.51 & 28.81 & \\
\hline \multirow[t]{5}{*}{ Ganoine-dorsal scale } & FONT 3-07-DVG-1 & 15.27 & 28.84 & 42.24 & 35.54 & $32.50 \pm 3.42$ \\
\hline & FONT 3-07-DVG-2 & 17.18 & 20.47 & 33.87 & 27.17 & \\
\hline & FONT 3-07-DVG-3 & 16.25 & 24.56 & 37.96 & 31.26 & \\
\hline & FONT 3-07-DVG-4 & 15.76 & 26.73 & 40.13 & 33.43 & \\
\hline & FONT 3-07-DVG-5 & 15.38 & 28.39 & 41.80 & 35.10 & \\
\hline
\end{tabular}

Minimum, maximum and mean temperatures were obtained by considering $0^{18} \mathrm{O}_{\mathrm{H} 2 \mathrm{O}}$ values of $-4.01 \%$, $-0.95 \%$ and $-2.48 \%$ (Domingo et al., 2007 ).

palaeotemperatures (Fricke et al., 1998; Barrick et al., 1999; Grimes et al., 2003, Amiot et al., 2004; Grimes et al., 2005). However, none of these studies had previously carried out a distinction among different types of scales. Table 2 shows $\delta^{18} \mathrm{O}_{\mathrm{PO} 4}$ values obtained from the ganoine from middle, posterior and anterior flank and dorsal body margin scales from the Fontllonga-3 site.

With the purpose of working out temperature value, Kolodny et al.'s (1983) Eq. (2) has been applied:

$T=113.3-4.38\left(\delta^{18} \mathrm{O}_{\text {PO4(VSMOW) }}-\delta^{18} \mathrm{O}_{\text {H2O(VSMOW })}\right)$

where $T$ is the temperature in degrees Celsius, $\delta^{18} \mathrm{O}_{\mathrm{POA}}$ (vsmow) is the phosphate oxygen isotope value of the sample and $\delta^{18} \mathrm{O}_{\mathrm{H} 2 \mathrm{O} \text { (vsmow) }}$ is the oxygen isotope value of the water from which the scale precipitated. It can be noticed that this equation presents two unknown variables: temperature and $\delta^{18} \mathrm{O}_{\mathrm{H} 2 \mathrm{O}}$. The latter was previously calculated by Domingo et al. (2007) who carried out a multiproxy palaeoclimatic study from the Fontllonga-3 site. Temperature values were estimated in this study by applying the $\mathrm{Ba} / \mathrm{Ca}$ palaeothermometer, the nearest living relative method and palaeobotanical evidence. These authors reported a range of $\delta^{18} \mathrm{O}_{\mathrm{H} 2 \mathrm{O}}$ values of between -4.01 and $-0.95 \%$ (VSMOW) for the Fontllonga- 3 fossil assemblage during the early Danian. Table 2 shows the results of minimum, mean and maximum temperatures (obtained by considering $\delta^{18} \mathrm{O}_{\mathrm{H} 2 \mathrm{O}}$ values of $-4.01 \%,-2.48 \%$ and $-0.95 \%$ VSMOW, respectively).

In the same way as observed in the $\mathrm{Ba} / \mathrm{Ca}$ palaeothermometer results, the mean $\delta^{18} \mathrm{O}_{\mathrm{PO} 4}$ temperature values obtained from the posterior flank scales are slightly higher $\left(30.53 \pm 3.28{ }^{\circ} \mathrm{C}\right)$ when compared to middle flank scales $\left(29.05 \pm 4.04{ }^{\circ} \mathrm{C}\right)$, although the difference is not statistically significant (Student $t$-test, $t=1.254$, $p=0.218$ ). Dorsal scales provide high temperature values $(32.50 \pm$ $3.42^{\circ} \mathrm{C}$ ) similar to the value furnished by posterior flank scales, whilst anterior flank scales show lower temperature values $\left(27.87 \pm 3.57{ }^{\circ} \mathrm{C}\right)$ more alike to that supplied by middle flank scales. 

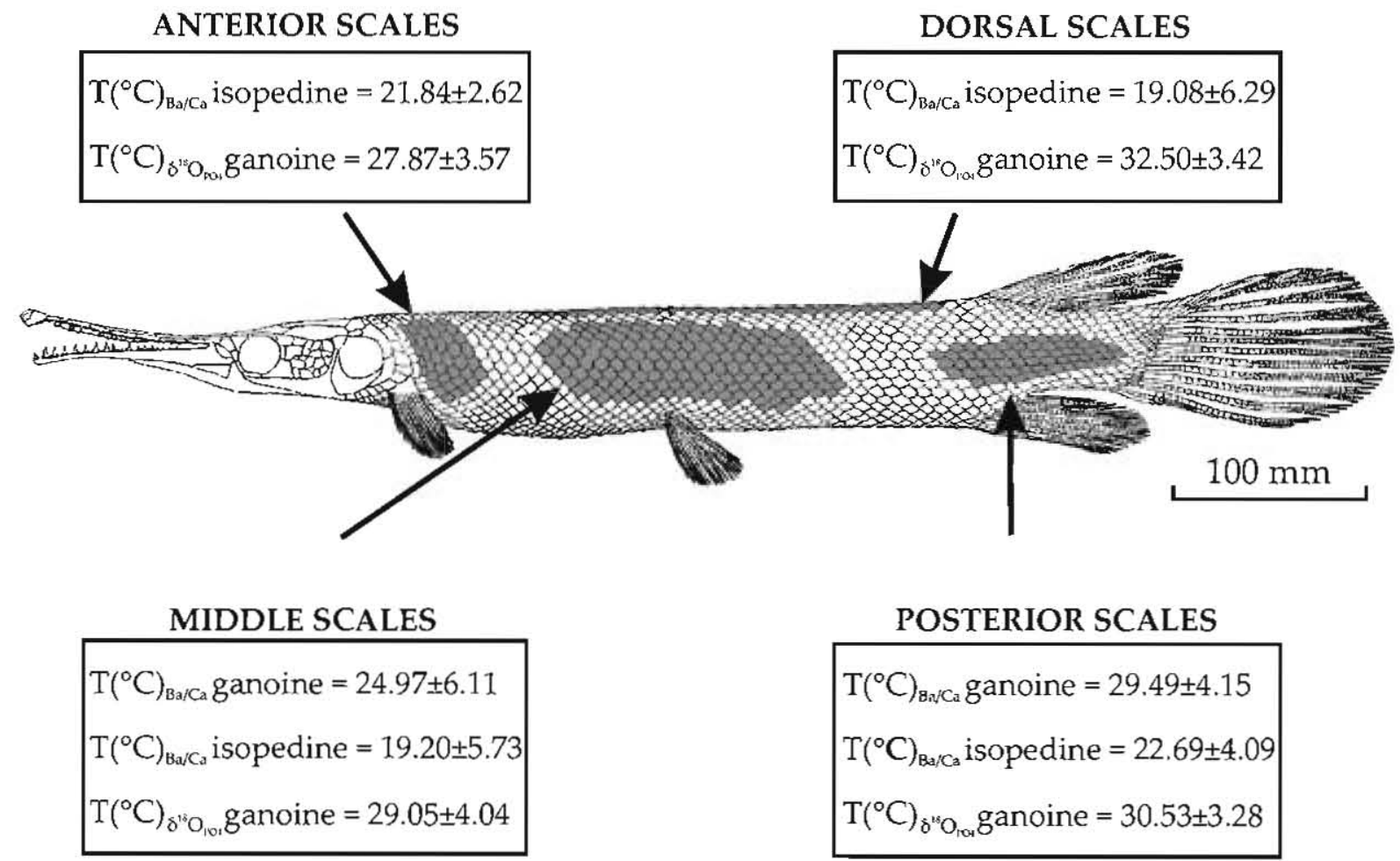

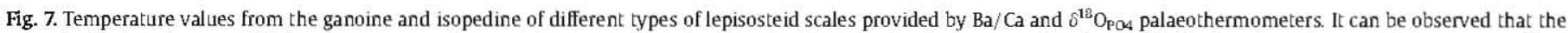

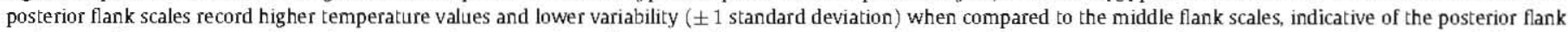

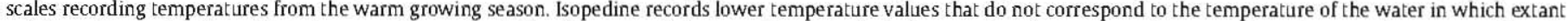

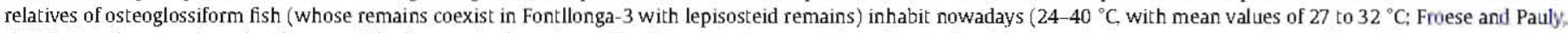

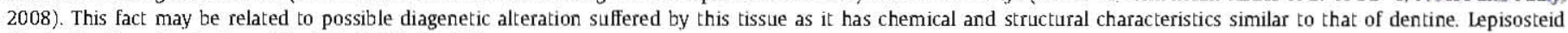
illustration from Gemballa and Bartsch (2002; Fig. 2B).

\subsection{Comparison of temperature values with respect to scale position}

Fig. 7 shows temperature values obtained by both the $\delta^{18} \mathrm{O}_{\mathrm{PO} 4}$ and $\mathrm{Ba} / \mathrm{Ca}$ palaeothermometers (when considering a $\mathrm{Ba} / \mathrm{Ca}$ value for the water of 0.0010 ) in lepisosteids from the Fontllonga-3 site according to the tissue used and the position of the scale. It can be observed that temperature values are higher for the ganoine of the posterior flank scales compared to the middle flank scales by $1-4{ }^{\circ} \mathrm{C}$ depending upon palaeothermometry method used. Furthermore, posterior flank scales have a lower variability in the palaeotemperature record compared to middle flank scales (Fig. 7). This is compatible with the fact that posterior flank scales show a more incomplete annual climatic record because of their preferred growth during the warmest parts of the season. Thus, posterior flank scales would correspond to what Grimes et al. (2003) assessed about lepisosteid scales (i.e. they only record temperatures from the growing season). The lower temperatures recorded by the middle flank scales on the other hand support the notion proposed by Fricike et al. (1998) according to whom scales of this kind record a homogenized seasonal signal. Furthermore, the high temperature values provided by the ganoine of the dorsal scales may also be indicating preferred growth during the warm season, similar to that of the posterior flank scales. Finally, because the ganoine of the anterior flank scales show relatively low temperature values this may indicate a similar growing pattem to that shown by the middle flank scales.

The same pattern shown by temperature values furnished by the ganoine of middle and posterior flank scales can be also seen in the isopedine results. That is, temperature values provided by the posterior flank scales are higher compared to those yielded by the middle flank scales indicating once more that posterior flank scales developed during the warmest part of the year, while middle flank scales respond to a more complete annual growth cycle. The temperature values from the isopedine are however all lower than the coexisting values obtained from the ganoine and their mean value when using a $\mathrm{Ba} / \mathrm{Ca}$ ratio of 0.0010 is below the temperature range of the water in which extant relatives of osteoglossiform fish inhabit nowadays. This tissue is therefore considered as less reliable for palaeoclimatic studies.

As enamel has always been considered as the most resistant and reliable biogenic tissue to use in the geochemical study of teeth, then it can be assumed that ganoine similarly is the most suitable tissue to use in the study of fish scales and as a consequence should reveal more accurate temperature values for the environment in which lepisosteids from the Fontllonga- 3 site inhabited. This appears to be the case as the mean temperature values showed by all the ganoine samples $\left(26.96 \pm 5.72{ }^{\circ} \mathrm{C}\right.$ and $29.82 \pm 3.76^{\circ} \mathrm{C}$ when considering the $\mathrm{Ba} / \mathrm{Ca}$ and $\delta^{18} \mathrm{O}_{\mathrm{PO4}}$ palaeothermometers, respectively) are more consistent with the range of temperature of the water in which extant relatives of osteoglossiform fish (whose remains have been found in Fontllonga-3 along with lepisosteid remains) inhabit nowadays $\left(24-40{ }^{\circ} \mathrm{C}\right.$, with mean values of 27 to $32{ }^{\circ} \mathrm{C}$; Froese and Pauly, 2008) than the temperature values furnished by the isopedine $\left(20.75 \pm 5.12{ }^{\circ} \mathrm{C}\right)$. This is in agreement with the isopedine being less resistant against postburial alteration since lower temperatures when using the $\mathrm{Ba} / \mathrm{Ca}$ palaeothermometer are a reflection of higher $\mathrm{Ba} / \mathrm{Ca}$ contents and therefore, this tissue may have incorporated a higher concentration of Ba (Fabig and Herrmann, 2002; Sponheimer and Lee-Thorp, 2006). Thus, in light of the REE, Ba/Ca and $\mathrm{Sr} / \mathrm{Ca}$ analyses, it is advisable not to use the isopedine with the aim of calculating absolute temperature values since this tissue shows similar chemical and structural characteristics to those shown by dentine and hence, it is more 
prone to suffer from diagenetic alteration when compared to the ganoine. This study demonstrates once again the preference of using enamel-type tissues versus bone-type tissues, such as other authors have previously stressed (Lee-Thorp and Van der Merwe, 1987, 1991; Koch et al., 1992; Ayliffe et al., 1994; Wang and Cerling, 1994; Cerling and Sharp, 1996; Sponheimer and Lee-Thorp, 1999; Hoppe et aL., 2003; Lee-Thorp and Sponheimer, 2003; Tütken et al., 2008).

\section{Conclusions}

In this study $\mathrm{REE}$ profiles, $\mathrm{Ba} / \mathrm{Ca}$ and $\mathrm{Sr} / \mathrm{Ca}$ ratios and $\delta^{18} \mathrm{O}_{\mathrm{PO} 4}$ values have been measured on the ganoine and isopedine of different types of scales (anterior, middle, and posterior flank and dorsal body margin) from juvenile lepisosteids from the Fontllonga-3 site (early Danian, Tremp Formation, South-Central Pyrenees, Spain) with the aim of detecting the most suitable kind of scale to be used in palaeoclimate studies. The REE "flat-shaped" patterns obtained in lepisosteid scales from Fontllonga-3 are indicative of the absence of late diagenesis and recrystallization and have allowed the identification of the palaeoenvironment in which the fish lived to be that of an estuary. Temperature values calculated by using $\mathrm{Ba} / \mathrm{Ca}$ and $\delta^{18} \mathrm{O}_{\mathrm{PO4}}$ palaeothermometers show a difference when comparing posterior and middle flank scales in such a way that posterior flank scales show consistently higher temperature values compared to the middle flank scales. This may be indicative of the fact that middle flank scales would be the most propitious scales to carry out geochemical studies on as they record a higher number of ganoine layers per unit of time and therefore, the geochemical signal recorded in them will correspond to the whole amplitude of the palaeoenvironmental and palaeoclimatic variations. On the other hand, the higher mean temperature value provided by the posterior flank scales might be indicative of more restricted growth related to the warmest parts of the year. Temperature values obtained from anterior flank scales follow a pattern similar to that showed by middle flank scales, whilst temperature values provided by dorsal scales resemble the pattern furnished by posterior flank scales.

Temperature values provided by the isopedine are lower than that obtained from ganoine and also remain below the expected range of temperatures for a water body in which extant osteoglossiform fish (whose remains have been found at the Fontllonga-3 site) inhabit nowadays. This fact along with REE results may be indicating some degree of diagenetic alteration of this tissue.

Based upon the results from this study, it is recommended that a distinction should be made between the different types of lepisosteid scales when performing geochemical analyses with the aim of calculating palaeotemperatures, since different scales have been shown to yield different climatic information. Moreover, isopedine should be rejected when calculating absolute temperature values due to its susceptibility to diagenetic alteration.

\section{Acknowledgments}

This work was supported by projects BTE 2002-1430 and CGL2006-04646 of the Plan Nacional I + D of the Spanish Ministerio de Educación y Ciencia conducted by N. L.-M. and by a FPU doctoral contract of the Ministerio de Educación y Ciencia to L. D. The work conducted by S. T. G. was supported by a Natural Environmental Research Council (NERC) New Investigators grant (NE/C507237/1). Authors are grateful to N. Grassineau and D. Lowry (Royal Holloway University of London, United Kingdom) for the help with the isotopic analyses and to M. I. Benito and M. Hernández Fernández (Universidad Complutense de Madrid, Spain) for their valuable comments. We also thank the editor F. Surlyk and the reviewers T. Tütken and S. Voigt for useful comments and suggestions that helped to substantially improve the final version of this manuscript.

\section{References}

Álvarez-Sierra, Ma.A., Arribas, Ma.E., Ardévol, L., Civis, J., Daams, R., Krauss, S., LópezMartínez, N., de la Peña, A., Soler, R., Vianey-Liaud, M., Lacasa, A., Marandat, B., Peláez-Campomanes, P., Sevilla, P., Sigé, B., 1994. El límite Cretácico-Terciario en la sección de Fontllonga (Cuenca de Ager, provincia de Lérida). II Congreso G.E.T. Jaca, Comunicaciones, pp. 23-26.

Amiot, R., Lécuyer, C., Buffetaut, E., Fluteau, F., Legendre, S., Martineau, F., 2004. Latitudinal temperature gradient during the Cretaceous Upper Campanian-Middle Maastrichtian: $\delta^{18} \mathrm{O}$ record of continental vertebrates. Earth and Planetary Science Letters 226, 255-272

Ayliffe, L.K., Chivas, A.R., Leakey, M.G., 1994. The retention of primary oxygen isotope compositions of fossil elephant skeletal phosphate. Geochimica et Cosmochimica Acta 58, 5291-5298.

Balter, V., Lécuyer, C., 2004. Determination of $\mathrm{Sr}$ and Ba partition coefficients between apatite and water from $5{ }^{\circ} \mathrm{C}$ to $60^{\circ} \mathrm{C}$ : a potential new thermometer for aquatic paleoenvimnments. Geochimica et Cosmochimica Acta 68, 423-432.

Barrick, R.E., Fischer, A.G., Showers, W.J., 1999. Oxygen isotopes from turtle bone: applications for terrestrial paleoclimates? Palaios 14, 186-191.

Billon-Bruyat, J.-P., Lécuyer, C., Martineau, F., Mazin, J.-M., 2005. Oxygen isotope compositions of Late Jurassic vertebrates remains from lithographic limestones of western Europe: implications for the ecology of fish, turtles, and crocodilians. Palaeogeography, Palaeoclimatology, Palaeoecology 216, 359-375.

Bryant, J.D., Luz, B., Froelich, P.N., 1994 Oxygen isotopic composition of fossil horse tooth phosphate as a record of continental paleoclimate. Palaeogeography, Palaeoclimatology, Palaeoecology 107, 303-316.

Bryant, J.D., Froelich, P.N., Showers, W.J., Genna, B.J., 1996. A tale of two quarries: biologic and taphonomic signatures in the oxygen isotope composition of tooth enamel phosphate from modern and Miocene equids. Palaios 11, 397-408.

Carroll, J., Falkner, K.K., Brown, E.T., Moore, W.S., 1993. The role of the GangesBrahmaputra mixing zone in supplying barium and ${ }^{226} \mathrm{Ra}$ to the Bay of Bengal. Geochimica et Cosmochimica Acta 57, 2981-2990.

Cerling, T.E., Sharp, ZD., 1996. Stable carbon and oxygen isotope analysis of fossil tooth enamel using laser ablation. Palaeogeography, Palaeoclimatology, Palaeoecology 126, 173-186.

Coffey, M., Dehairs, F., Collete, O., Luther, G., Church, T., Jickells, T., 1997. The behaviour of dissolved barium in estuaries. Estuarine, Coastal and Shelf Science 45, 113-121.

Colbert, D., McManus, J., 2005. Importance of seasonal variability and coastal processes on estuarine manganese and barium cycling in a Pacific Northwest estuary. Continental Shelf Research 25, 1395-1414.

Domingo, L., López-Martínez, N., Soler-Gijón, R., Grimes, S.T., 2007. A multi-proxy geochemical investigation of the early Paleocene (Danian) continental palaeoclimate at the Fontllonga-3 site (South Central Pyrenees, Spain). Palaeogeography, Palaeoclimatology, Palaeoecology 256, 71-85.

Elsdon, T.S., Gillanders, B.M., 2003. Relationship between water and otolith elemental concentrations in juvenile black bream Acanthopagrus butcheri. Marine Ecology Progress Series 260, 263-272.

Elsdon, T.S., Gillanders, B.M., 2005. Alternative life-history patterns of estuarine fish: barium in otoliths elucidates freshwater residency. Canadian Journal of Fisheries and Aquatic Sciences 62, 1142-1152.

Elsdon, T.S., Gillanders, B.M., 2006. Temporal variability in strontium, calcium barium, and manganese in estuaries: implications for reconstructing environmental histories of fish from chemicals in calcified tissues. Estuarine, Coastal and Shelf Science 66, 147-156.

Fabig, A., Herrmann, B., 2002. Trace elements in buried human bones: intra-population variability of $\mathrm{Sr} / \mathrm{Ca}$ and $\mathrm{Ba} / \mathrm{Ca}$ ratios - diet or diagenesis? Naturwissenschaften 89 , 115-119.

Feist, M., Colombo, F., 1983. La limite Crétacé-Tertiaire dans le nord-est de l'Espagne, du point de vue des charophytes. Géologie Méditerranéenne 10, 303-326.

Feranec, R.S., 2004. Isotopic evidence of saber-tooth development, growth rate, and diet from the adult canine of Smilodon fatalis from Rancho La Brea. Palaeogeography, Palaeoclimatology, Palaeoecology, 206, 303-310.

Feranec, R.S., MacFadden, B.J., 2000. Evolution of the grazing niche in Pleistocene mammals from Florida: evidence from stable isotopes. Palaeogeography, Palaeoclimatology, Palaeoecology, 162, 155-169.

Fernández-Marrón, M.T., López-Martínez, N., Fonollá-Ocete, J.F., Valle-Hernández, M.F., 2004. The palynological record across the Cretaceous-Tertiary boundary in differing palaeogeographical settings from the southern Pyrenees, Spain. In: Beaudoin, A.B., Head, M.J. (Eds.), The Palynology and Micropaleontology of Boundaries. Special Publications - Geological Society of London, vol. 230, pp. 243-255.

Fox, D.L, Fisher, D.C., 2004. Dietary reconstruction of Miocene Gomphotherium (Mammalia, Proboscidea) from the Great Plains region, USA, based on the carbon isotope composition of tusk and molar enamel. Palaeogeography, Palaeoclimatology, Palaeoecology 206, 311-335.

Fricke, H.C., Pearson, D.A., 2008. Stable isotope evidence for changes in dietary niche partitioning among hadrosaurian and ceratopsian dinosaurs of the Hell Creek Formation, North Dakota. Paleobiology 34, 534-552.

Fricke, H.C., Wing, S.L., 2004. Oxygen isotope and paleobotanical estimates of temperature and delta ${ }^{18} \mathrm{O}$-latitude gradients over North America during the early Eocene. American Journal of Science 304, 612-635.

Fricke, H.C., Clyde, W.C., O'Neil, J.R., Gingerich, P.D., 1998. Evidence for rapid climate change in North America during the latest Paleocene thermal maximum: oxygen isotope compositions of biogenic from the Bighorn Basin (Wyoming). Earth and Planetary Science Letters 160, 193-208.

Fricke, H.C., Rogers, R.R., Backlund, R., Dwyer, Ch.N., Echt, S., 2008. Preservation of primary stable isotope signals in dinosaur remain, and environmental gradients of the Late Cretaceous of Montana and Alberta. Palaeogeography, Palaeoclimatology, Palaeoecology 266, 13-27 
Froese, R., Pauly. D. (Eds.), 2008. FishBase. World Wide Web electronic publication. www fishbase org, version (10/2008)

Galbritn, B., Feist, M., Colonbo, F., Kocchia, R., Tantbareai1, Y., 1993. Magnetostratigraphy and biostratigraphy of Cretaceous-Tertiary continental deposits, Ager basin province of Lerida, Spain. Palaeogeography, Palaeoclimatology, Palaeoecology 102. $41-52$.

Gemballa, S., Bartsch, P., 2002. Architecture of the integument in lower Teleostomes: functional morphology and evolutionary implications. Journal of Morphology 253, $290-309$.

Grimes, S.T., Mattey, D.P., Hooker, II., Collinson, M.E., 2003. Paleogene paleoclimate reconstruction using oxygen isotopes from land and freshwater organisms: the use of multiple paleoproxies. Geochimica et Cosmochimica Acia 67, 4033-4047.

Grimes, S.T., Hooker, J.J, Collinson, ME, Mattey, D.P. 2005. Summer temperatures of late Eocene to early Oligocene freshwaters. Geology 33, $189-192$.

Hoppe, K.A., Koch, P.L., Furutani, T.T, 2003. Assessing the preservation of biogenic strontium in fossil bones and tooth enamel. International Joumal of Osteoarchaelogy $13,20-28$.

Iglesias Martín, I.. Soler-Gijón, R, 1999. Un nuevo método de estudio de la ciclicidad en el crecimiento de las escamas ganoideas, aplicado a Fontilonga 3 (Paleoceno inferior, Lleida). Coloquios de Paleontología 50, 127-149.

Kedves, M., 1982. Palynology of the Thanetian layers of Menat. Palaentographica B 182, $87-150$

Koch, P.L., Zachos, IC., Gingerich, P.D., 1992. Correlation between isotope records in marine and continental carbon reservoirs near the Paleocene/Eocene boundary. Nature 358, 319-322.

Kolodny, Y., luz, B., Navon, 0, 1983. Oxygen isotope variations in phosphate of biogenic apatites. I. Fish- bone apatite-rechecking the rules of the game. Earth and Planetary Science lerters 64, 398-404.

Iéciver, C. Picard, S., Garcia, I-P., Sheppard, S.MF, Grandjean, P., Dromart, G, 2003 a Thermal evolution of Tethyan surface waters during the Middle-late Jurassic: evidence from ${ }^{18} 0$ values of marine fish teech. Paleoceanography $18,21(1)-21(16)$.

lécuyer, C, Bogey, C., Garcia, J.-P., Grandjean, P., Barrat, J.-A., Floquet, M., Bardet, N., Pereda-Superbiola, X., 2003b. Stable isotope composition and rare earth element content of vertebrate remains from the Late Cretaceous of northem Spain (Laño): did the environmental record survive? Palaeogeography. Palaeoclimatology Palaeoecology $193,457-471$.

Lee-Thorp, J.A., Van der Merwe, N.J., 1987. Carbon isotope analysis of fossil bone apatite South African Joumal of Science 83, 712-715.

Lee-Thorp, J.A., Van der Merwe, N.J., 1991. Aspects of the chemistry of modern and fossil biological apatites. journal of Archaeological Science 18. 343--354

Iee Thorp, ]A., Sponheimer, M., 2003. Three case studies used to reassess the reliability of fossil bone and enamel isotope signals for paleodietary studies. Joumal of Anthropological Archaeology 22, 208-216.

Li, Y.L., Chan, L-H., 1979. Desorption of $\mathrm{Ba}$ and ${ }^{22} \mathrm{E}_{\mathrm{Ra}}$ from river-borne sediments in the Hudson estuary. Earth and Planetary Science Letters $43,343-350$

Lindars, E.S., Grimes, S.T., Mattey, D.P., Collinson, M.E, Hooker. J., Jones, T.P., 2001 Phosphate $\delta^{15} 0$ determination of modem rodent teeth by direct laser fluorination: an appraisal of methodology and potential application to palaeoclimate reconstruction. Geochimica et Cosmochimica Acta 65, 2535-2548.

López-Marlinez, N. Ardévol, L. Arribas, Ma E. Civis, J. González-Delgado, A. 1998. The geological record in non-marine environments around the $\mathrm{K} / \mathrm{T}$ boundary (Tremp Formation, Spain). Bulletin de la Société Gêologique de France 169, 11-20.

López-Martinez, N., Fernández-Marrón, Ma.T., Valle, M.F., 1999. The succession of vertebrates and plancs across the Cretaceous-Tertiary boundary in the Tremp Formation, Ager Valley (South-Central Pyrenees, Spain). Geobios 32, 617-627.

Matson, S.D., Fox, D.L., 2008. Can oxygen isotopes from turtle bone be used to reconstruct paleoclimates? Palaios $23,24-34$.

Mayr, C., Thümmler, B., Windmaier, G., Altenbach, A.V., Köhler, H., Tiedemann, R., 1999 New data alout the Maastrichtian/Danian transition in the southern Pyrenees (Ager Basin Catalonia, Spain). Revista española de Micropaleontología 31, 357--368

Mey, P., Nagtegaal, P.J.C., Roberti, K.I. Hartevelt, I. 1968. Lithostratigraphic subdivision of post-Hercynian deposits in the south-central Pyrenees, Spain. Leidse Geologische Mededelingen 41, 221-228.

Milton, D. Halliday, I., Sellin, M., Marsh, R., Staunton-Smith, I., Woodhead, J., 2008. The effect of habitat and environment history on otolith chemistry of barramundi Lates calcarfer in estuarine populations of a regulated tropical river. Estuarine, Coastal and Shelf Science $78,301-315$.

Naglegaal, P.J.C, Van Vliet, A., Brotwer, I., 1983. Syntectonic coastal offlap and concurrent turbidite deposition: the Upper Cretaceous Aren sandstone in the South-Central Pyrenees, Spain. Sedimentary Geology 34, 185-218.
Nozaki, Y., Yamamoto, Y., Manaka, T., Amakawa, H., Snidvongs, A., 2001. Dissolved barium and ratilum isotopes in the Chao Phraya River estuarine mixing zone in Thailand. Continental Shelf Research 21, 1435-1448.

Peláez-Campomanes, P., López-Martínez, N. Alvarez Sierra, M.A., Daams, R, 2000. The earliest mammal of the European Paleocene: the multituberculate Hainina. Journal of Paleontology 74, 701-711.

Pucéat, E., Lécuyer, C., Sheppard, S.M.F., Dromart, G., Rebouler, S., Grandjean, P., 2003. Thermal evolution of Cretaceots Tethyan marine waters inferred from oxygen isotope composition of fish tooth enamels. Paleoceanography $18,7-1-7-12$

Reynard, B., Lécuyer, C., Grandjean, P., 1999. Crystal-chemical controls on rare earth element concentrations in fossil biogenic apatites and implications for paleoenvironmental reconstructions. Chemical Geology 155, 233-241.

Robertson, C.R., Zeug, S.C., Winemiller, K.O., 2008. Associations between hydrological connectivity and resource partitioning among sympatric gar species (Lepisostei dae) in a Texas river and associated oxbows. Ecology of Freshwater Fish 17, 1.19-129.

Schnitz, B., Pujalte, V, 2003. Sea-level, humidity and land-erosion records across the initial Eocene thermal maximum from a continental-marine transect in northem Spain. Geology 31, 689--692.

Schultze, H.P., 1996. The scales of Mesozoic actinopterygians. In: Arratia, G., Viohi, G (Eds.), Mesozoic Fishes. Systematic and Paleoecology. Pfeil, München, pp. 83-93.

Sire, I.Y., 1994. Light and TEM study of nonregenerated and experimentally regenerated scales of Lepisosteus oculatus (Holostei) with particular attention to ganoine formation. The Aratomical Record 240, 189-207.

Sire, J-Y., Akimenko, M.-A., 2004. Scale development in fish: a review, with description of sonic hedgehog (shh) expression in the zebrafish (Donio tetio). International Journal of Developmental Biology 48, 233-247.

Sire, J.-Y.. Allizard, F. Babiar, O.. Bourguignon, I., Qtuilhac, A., 1997. Scale development in zebrafish (Danio retio), journal of Anatomy 190, 545-561.

Soler-Giijon, R, de la Peña, A, 1995. Fishes from the Cretaceolis-Tertiary boundary interval of the Ager basin, lerida province (Spain). Terra Nostra 65, 73--74

Soler-Gijón, R., López-Martinez, N., 2005. Late Cretaceous-early Paleocene osteichthyans from the Fontllonga Section (South-central Pyrenees, Spain): new record and implications. In: Poyato-Ariza, F. (Ed.), Fourth International Meering on Mesozoii Fishes - Systematics, Homology, and Nomenclature, Madrid Servicio de Publicaciones de la Innersidad Autónoma de Madrid, UAM Ediciones, pp. 229-233.

Sponheimer, M., Lee-Thorp, I.A., 1999. The alteration of enamel carbonate environments during fossilisarion. Journal of Archaeological Science 26, 143-150.

Sponheimer, M., Lee-Thorp, I.A., 2006. Enamel diagenesis at South African Australopith sites: implications for paleoecological reconstruction with trace elements. Geochimica et Cosmochimica Acta 70, 1644-1654.

Taylor, S.k., Mclennan, S.M., 1985. The Continental Crust: Its Composition and Evolition. Blackwell, Oxford

Thomson, K.S. McCune, A.R., 1984. Development of the scales in Lepisostetss as a model for scale formation in fossil fishes. Zoological Joumal of the Linnean Society 82 , $73-86$.

Trueman, CN., 1999. Rare earth element geochemistry and taphonomy of terrestrial ver tebrate assemblages. Palaios $14,555-568$.

Tütken, T., Pfretzschner, H.-U., Vennemann, T.W., Sun, G., Wang, Y.D., 2004. Paleobiology and skeletochronology of Jurassic dinosaurs: implications from the histology and oxygen isotope compositions of bones. Palaeogeography, Palaeoclimatology, Palaenecology 206, 217-238.

Tótken, T., Vennemann, T.W., Janz, H., Heizmann, E.P.J, 2006. Palaeoenvironment and palaenclimate of the Middle Miocene lake in the Steinheim basin, SW Germany: a reconstruction from $\mathrm{C}, \mathrm{O}$, and $\mathrm{Sr}$ isotopes of fossil remains. Palaeogeography. Palaeoclinatology, Palaeoecology 241, 457-491.

Tiatken, T., Vennemann, T.W., Pfretzschnex, H.-U., 2008. Early dagenesis of bone and cooth apatite in fluvial and marine settings: constraints from combined oxygen isotope, nitrogen and REE analysis. Palaeogeography, Palaeoclimatology, Palaeoe. cology $266,254-268$.

Wang, Y., Cerling, T.E. 1994. A model of fossil tooth and bone diagenesis: implications for palaeodiet reconstruction from stable isotopes. Palaeogeography, Palaeoclima tology, Palaeoecology 107, 281-289.

Wells, B.K., Bath, G.E., Thorrold, S.R., Jones, C.M., 2000. Incorporation of strontium, cadmilum, and barium in jivenile spot (Leiostomus xonthurus) scales reflects water chemistry. Canadian Joumal of Fisheries and Aquatic Sciences 57, 2122-2129.

Wells, B.K., Rieman, B.E., Claycon, J.L, Horan, D.L. Jones, C.M., 2003. Relationships between water, orolith and scale chemistries of westslope cutrhroar trout from the Coeur d'Alene River, Idaho: the potential application of hard part chemistry to describe movements in freshwater. Transactions of the American Fisheries Society $132,409-424$ 